National Water-Quality Assessment Program

\title{
Environmental Setting of the Sugar Creek and Leary Weber Ditch Basins, Indiana, 2002-04
}

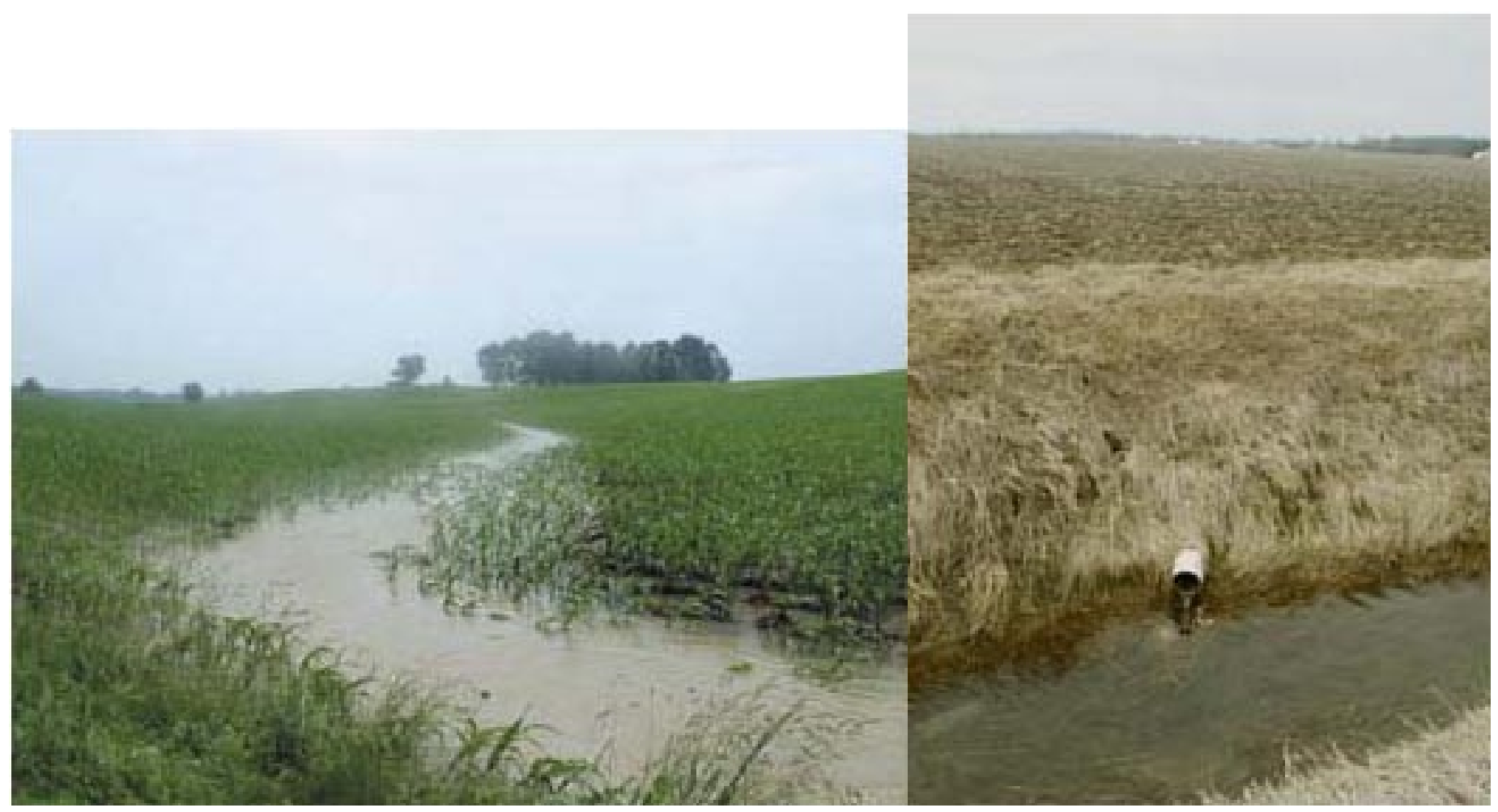

Scientific Investigations Report 2006-5170 
Cover. Photograph of localized flooding in a cornfield within the Sugar Creek Basin, Indiana, taken after a storm in mid-June 2003 (left). Photograph of a tile drain lowering the water table of a cornfield in the Leary Weber Ditch Basin, Indiana, taken prior to planting in March 2003 (right). 


\section{Environmental Setting of the Sugar Creek and Leary Weber Ditch Basins, Indiana, 2002-04}

By Timothy R. Lathrop

National Water-Quality Assessment Program

Scientific Investigations Report 2006-5170 


\section{U.S. Department of the Interior DIRK KEMPTHORNE, Secretary}

\section{U.S. Geological Survey \\ Mark D. Myers, Director}

\section{U.S. Geological Survey, Reston, Virginia: 2006}

For product and ordering information:

World Wide Web: http://www.usgs.gov/pubprod

Telephone: 1-888-ASK-USGS

For more information on the USGS—-the Federal source for science about the Earth, its natural and living resources, natural hazards, and the environment:

World Wide Web: http://www.usgs.gov

Telephone: 1-888-ASK-USGS

Any use of trade, product, or firm names is for descriptive purposes only and does not imply endorsement by the U.S. Government.

Although this report is in the public domain, permission must be secured from the individual copyright owners to reproduce any copyrighted materials contained within this report.

Suggested citation:

Lathrop, T.R., 2006, Environmental Setting of the Sugar Creek and Leary Weber Ditch Basins, Indiana, 2002-2004: U.S. Geological Survey Scientific Investigations Report 2006-5170, 27 p. 


\section{Foreword}

The U.S. Geological Survey (USGS) is committed to providing the Nation with credible scientific information that helps to enhance and protect the overall quality of life and that facilitates effective management of water, biological, energy, and mineral resources (http://www.usgs.gov/). Information on the Nation's water resources is critical to ensuring long-term availability of water that is safe for drinking and recreation and is suitable for industry, irrigation, and fish and wildlife. Population growth and increasing demands for water make the availability of that water, now measured in terms of quantity and quality, even more essential to the long-term sustainability of our communities and ecosystems.

The USGS implemented the National Water-Quality Assessment (NAWQA) Program in 1991 to support national, regional, State, and local information needs and decisions related to water-quality management and policy (http://water. usgs.gov/nawqa). The NAWQA Program is designed to answer: What is the condition of our Nation's streams and ground water? How are conditions changing over time? How do natural features and human activities affect the quality of streams and ground water, and where are those effects most pronounced? By combining information on water chemistry, physical characteristics, stream habitat, and aquatic life, the NAWQA Program aims to provide science-based insights for current and emerging water issues and priorities. From 1991-2001, the NAWQA Program completed interdisciplinary assessments and established a baseline understanding of water-quality conditions in 51 of the Nation's river basins and aquifers, referred to as Study Units (http://water.usgs.gov/ nawqa/studyu.html).

Multiple national and regional assessments are ongoing in the second decade (2001-2012) of the NAWQA Program as 42 of the 51 Study Units are reassessed. These assessments extend the findings in the Study Units by determining status and trends at sites that have been consistently monitored for more than a decade and filling critical gaps in characterizing the quality of surface water and ground water. For example, increased emphasis has been placed on assessing the quality of source water and finished water associated with many of the Nation's largest community water systems. During the second decade, NAWQA is addressing five national priority topics that build an understanding of how natural features and human activities affect water quality and establish links between sources of contaminants, the transport of those contaminants through the hydrologic system, and the potential effects of contaminants on humans and aquatic ecosystems. Included are topics on the fate of agricultural chemicals, effects of urbanization on stream ecosystems, bioaccumulation of mercury in stream ecosystems, effects of nutrient enrichment on aquatic ecosystems, and transport of contaminants to public-supply wells. These topical studies are conducted in those Study Units most affected by these issues; they comprise a set of multi-Study-Unit designs for systematic national assessment. In addition, national syntheses of information on pesticides, volatile organic compounds (VOCs), nutrients, selected trace elements, and aquatic ecology are continuing.

The USGS aims to disseminate credible, timely, and relevant science information to address practical and effective water-resource management and strategies that protect and restore water quality. We hope this NAWQA publication will provide you with insights and information to meet your needs and will foster increased citizen awareness and involvement in the protection and restoration of our Nation's waters.

The USGS recognizes that a national assessment by a single program cannot address all water-resource issues of interest. External coordination at all levels is critical for costeffective management, regulation, and conservation of our Nation's water resources. The NAWQA Program, therefore, depends on advice and information from other agenciesFederal, State, regional, interstate, Tribal, and local—as well as nongovernmental organizations, industry, academia, and other stakeholder groups. Your assistance and suggestions are greatly appreciated.
Robert M. Hirsch Associate Director for Water 


\section{Contents}

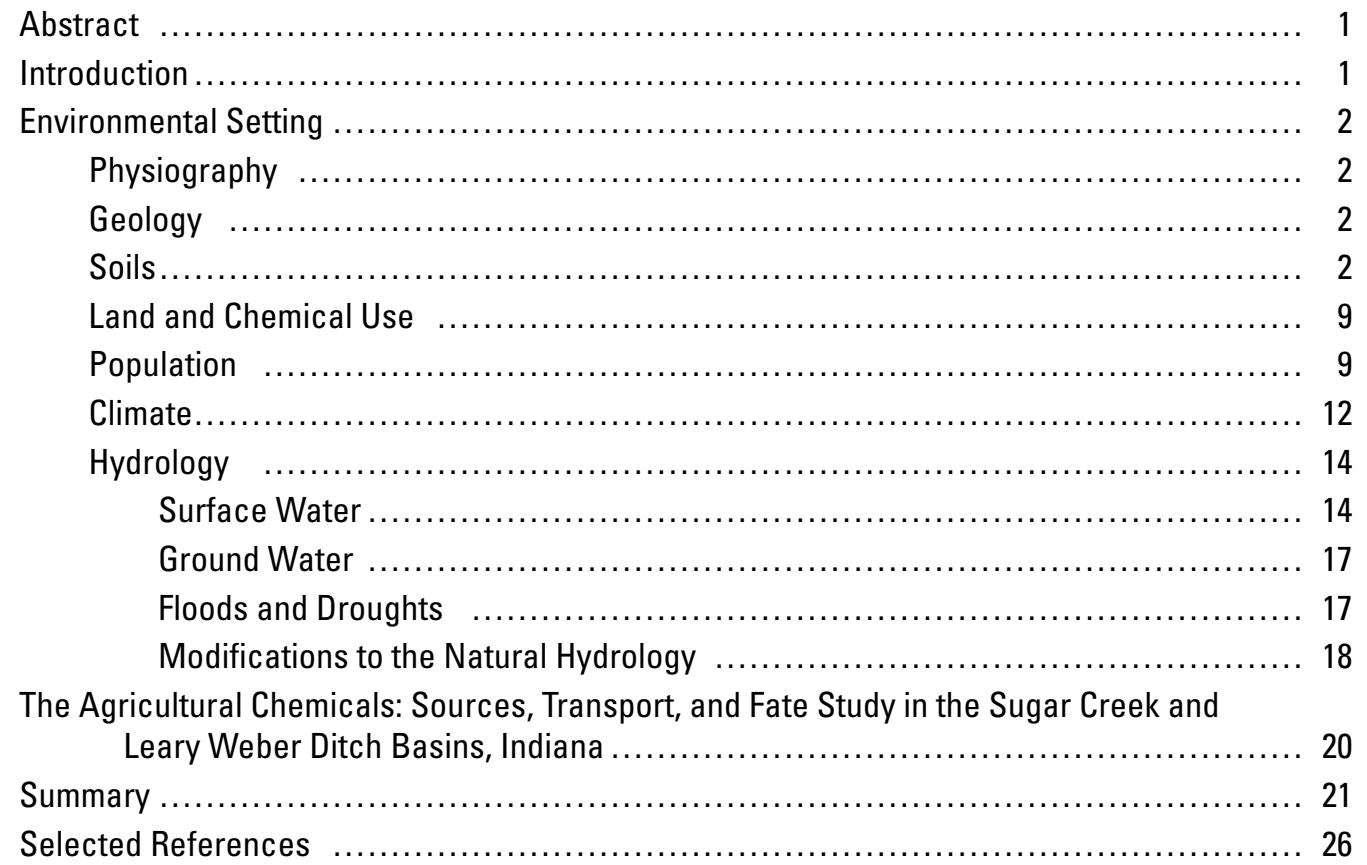

\section{Figure}

1.-3. Maps showing-

1. Location of the Leary Weber Ditch and Sugar Creek Basins, Indiana .......... 3

2. Physiographic relief in the Leary Weber Ditch and Sugar Creek Basins ........ 4

3. Generalized bedrock geology in the Leary Weber Ditch and Sugar Creek Basins

4. Cross section of geologic strata in the Leary Weber Ditch and Sugar Creek Basins

5.-7. Maps showing-

5. Generalized soil types in the Leary Weber Ditch and Sugar Creek Basins ..... 8

6. Land use in the Leary Weber Ditch and Sugar Creek Basins ................ 10

7. Population density by U.S. Census block group in the Leary Weber Ditch and Sugar Creek Basins, 2000

8.-10. Graphs showing-

8. Population growth in Hancock County, Indiana, 1790 to 2005

9. Normal monthly temperatures and monthly mean temperatures during water years 2003 and 2004 in the Sugar Creek Basin ....

10. Precipitation in the Sugar Creek Basin, Indiana, 1948-2004 ................ 15 
11. Map showing location of U.S. Geological Survey water-quality and streamflowgaging stations in the Leary Weber Ditch and Sugar Creek Basins...

12.-13. Graphs showing-

12. Annual discharge at U.S. Geological Survey streamflow-gaging station Sugar Creek at New Palestine, IN, water years 1968 to 2004.

13. Daily discharge at U.S. Geological Survey streamflow-gaging stations Sugar Creek at New Palestine, IN, and Leary Weber Ditch at Mohawk, IN, water years 2003 and 2004

14. Aerial photo showing location of sampling sites in Leary Weber Ditch Basin

\section{Tables}

1. Generalized stratigraphic column for the Leary Weber Ditch and Sugar Creek Basins, Indiana

2. Summary of land use and land cover in the Leary Weber Ditch and Sugar Creek Basins

3. Summary of estimated herbicide, insecticide, and fertilizer use in the Leary Weber Ditch and Sugar Creek Basins

4. Summary of mean daily discharge characteristics at selected U.S. Geological Survey streamflow-gaging stations in the Leary Weber Ditch and Sugar Creek Basins

5. Major features of aquifer settings in the Leary Weber Ditch and Sugar Creek Basins

6. Equipment list for the eight Agricultural Chemicals: Sources, Transport, and Fate study sites in the Leary Weber Ditch and Sugar Creek Basins 


\section{Conversion Factors, Abbreviations, and Datums}

\begin{tabular}{|c|c|c|}
\hline Multiply & By & To obtain \\
\hline inch per year (in/yr) & 25.4 & millimeter per year (mm/yr) \\
\hline foot $(\mathrm{ft})$ & 0.3048 & meter $(\mathrm{m})$ \\
\hline foot per day (ft/d) & 0.3048 & meter per day $(\mathrm{m} / \mathrm{d})$ \\
\hline foot per day per foot $[(\mathrm{ft} / \mathrm{d}) / \mathrm{ft}]$ & 1 & meter per day per meter $[(\mathrm{m} / \mathrm{d}) / \mathrm{m}]$ \\
\hline foot squared per day $\left(\mathrm{ft}^{2} / \mathrm{d}\right)^{*}$ & 0.09290 & meter squared per day $\left(\mathrm{m}^{2} / \mathrm{d}\right)$ \\
\hline foot per mile (ft/mi) & 0.1894 & meter per kilometer $(\mathrm{m} / \mathrm{km})$ \\
\hline cubic foot per second $\left(\mathrm{ft}^{3} / \mathrm{s}\right)$ & 0.02832 & cubic meter per second $\left(\mathrm{m}^{3} / \mathrm{s}\right)$ \\
\hline $\begin{array}{l}\text { cubic foot per second per square mile } \\
{\left[\left(\mathrm{ft}^{3} / \mathrm{s}\right) / \mathrm{mi}^{2}\right]}\end{array}$ & 0.01093 & $\begin{array}{l}\text { cubic meter per second per square } \\
\text { kilometer }\left[\left(\mathrm{m}^{3} / \mathrm{s}\right) / \mathrm{km}^{2}\right]\end{array}$ \\
\hline $\begin{array}{l}\text { cubic foot per day per foot } \\
{\left[\left(\mathrm{ft}^{3} / \mathrm{d}\right) / \mathrm{ft}\right]}\end{array}$ & 0.09290 & $\begin{array}{l}\text { cubic meter per day per meter } \\
{\left[\left(\mathrm{m}^{3} / \mathrm{d}\right) / \mathrm{m}\right]}\end{array}$ \\
\hline mile (mi) & 1.609 & kilometer $(\mathrm{km})$ \\
\hline mile per hour $(\mathrm{mi} / \mathrm{h})$ & 1.609 & kilometer per hour $(\mathrm{km} / \mathrm{h})$ \\
\hline square mile $\left(\mathrm{m}^{2}\right)$ & 2.590 & square kilometer $\left(\mathrm{km}^{2}\right)$ \\
\hline $\begin{array}{l}\text { people per square mile } \\
\left(\text { people } / \mathrm{mi}^{2}\right)\end{array}$ & 0.3861 & $\begin{array}{l}\text { people per square kilometer } \\
\left(\text { people } / \mathrm{km}^{2}\right)\end{array}$ \\
\hline acre & 0.4047 & hectare (ha) \\
\hline acre-foot (acre-ft) & 1,233 & cubic meter $\left(\mathrm{m}^{3}\right)$ \\
\hline pound per acre (lb/acre) & 1.121 & kilogram per hectare $(\mathrm{kg} / \mathrm{ha})$ \\
\hline $\begin{array}{l}\text { pound per acre per year } \\
\text { [(lb/acre }) / y r]\end{array}$ & 1.121 & $\begin{array}{l}\text { kilogram per hectare per year } \\
{[(\mathrm{kg} / \mathrm{ha}) / \mathrm{yr}]}\end{array}$ \\
\hline $\begin{array}{l}\text { ton per acre per year } \\
\text { (ton/acre/yr) }\end{array}$ & 2.242 & $\begin{array}{l}\text { megagram per hectare per year } \\
(\mathrm{Mg} / \mathrm{ha} / \mathrm{yr})\end{array}$ \\
\hline bushel (bu) & 0.03524 & cubic meter $\left(\mathrm{m}^{3}\right)$ \\
\hline gallon per minute (gal/min) & 0.06309 & liter per second (L/s) \\
\hline million gallons per day (Mgal/d) & 0.04381 & cubic meter per second $\left(\mathrm{m}^{3} / \mathrm{s}\right)$ \\
\hline
\end{tabular}

*Transmissivity: The standard unit for transmissivity is cubic foot per day per square foot times foot of aquifer thickness [(f $\left.\left.\mathrm{ft}^{3 / \mathrm{d}}\right) / \mathrm{ft}^{2}\right] \mathrm{ft}$. In this report, the mathematically reduced form, foot squared per day $\left(\mathrm{ft}^{2} / \mathrm{d}\right)$, is used for convenience.

Temperature in degrees Fahrenheit $\left({ }^{\circ} \mathrm{F}\right)$ may be converted to degrees Celsius $\left({ }^{\circ} \mathrm{C}\right)$ as follows:

$$
{ }^{\circ} \mathrm{C}=\left({ }^{\circ} \mathrm{F}-32\right) / 1.8
$$


Vertical coordinate information is referenced to the North American Vertical Datum of 1988 (NAVD 88).

Vertical coordinate information for figure 4 only is referenced to the National Geodetic Vertical Datum of 1929 (NGVD of 1929).

Horizontal coordinate information is referenced to the North American Datum of 1988 (NAD 88).

Concentrations of chemical constituents in water are given either in milligrams per liter (mg/L) or micrograms per liter $(\mu \mathrm{g} / \mathrm{L})$.

Water year in the U.S. Geological Survey reports dealing with surface-water supply is the 12-month period, 0 ctober 1 through September 30. The water year is designated by the calendar year in which it ends and which includes 9 of the 12 months. Thus, the year ending September 30,1985 , is called the "1985 water year." 
This page is intentionally blank. 


\title{
Environmental Setting of the Sugar Creek and Leary Weber Ditch Basins, Indiana, 2002-04
}

\author{
By Timothy R. Lathrop
}

\section{Abstract}

The Leary Weber Ditch Basin is nested within the Sugar Creek Basin in central Indiana. These basins make up one of the five study sites in the Nation selected for the Agricultural Chemicals: Sources, Transport, and Fate topical study, a part of the U.S. Geological Survey's National Water-Quality Assessment Program. In this topical study, identifying the natural factors and human influences affecting water quality in the Leary Weber Ditch and Sugar Creek Basins are the focus of the assessment. A detailed comparison between the environmental settings of these basins is presented. Specifics of the topical study design as implemented in the Leary Weber Ditch and Sugar Creek Basins are described.

The Leary Weber Ditch and Sugar Creek Basins have moderate temperatures with well-defined winter and summer seasons. The mean annual precipitation is 39.5 inches, with the majority of rainfall in spring and early summer and the lowest amount of precipitation in winter. Yearly, an average of 25 inches of moisture moves into the atmosphere as a result of evapotranspiration.

Physiographically, both basins are contained completely within the New Castle Till Plains and Drainageways. The gradients of the valleys of Leary Weber Ditch and Sugar Creek differ substantially. Most of the Sugar Creek Basin and the entire Leary Weber Ditch Basin overlie a combination of Devonian limestone and dolomite bedrock. Unconsolidated materials (sand and gravel) overlie much of the bedrock in the basins. Soils are either loam or silt loam, generally deep, poorly drained, medium textured, and nearly level. The potential for surface erosion is negligible because runoff is slow. Available water capacity is high. Natural fertility and organic matter are moderate. Soils are naturally suited to row crops.

Agriculture is the principal land use in the Leary Weber Ditch and Sugar Creek Basins. Respectively, 87 percent and 75 percent of the total land area in these basins are used for row crops. The cropped areas within the basins are divided nearly equally between corn and soybeans. Farming practices in the area employ a wide range of tools to promote growth and inhibit vegetative competition; these include the use of fertilizers, herbicides, and pesticides. Tile drains are used extensively to improve yields and make the soils farmable. Irrigation and manure application in the study area are minimal.
Most of the study area is in Hancock County, Indiana. The county population is approximately 61,000 . There are no large cities in either basin; most residents live in small communities or rural areas. Water use in Hancock County totalled 6.37 million gallons per day during 2002. Drinking water comes entirely from ground water.

The U.S. Geological Survey operates streamflow-gaging stations at Sugar Creek at New Palestine and at Leary Weber Ditch at Mohawk within the study area. Mean daily streamflow for Sugar Creek is higher than streamflow at Leary Weber Ditch. Through most of its length, Sugar Creek is a gaining stream and base flow is supported by ground-water sources. At Leary Weber Ditch, there is little to no streamflow when tile drains are dry. Modifications to the natural hydrology of the study area include a large system of tile drains, the intersection of Sugar Creek by several major roads, and outflows from nearby wastewater-treatment plants. Leary Weber Ditch is affected only by tile drains.

\section{Introduction}

Sugar Creek Basin in central Indiana is one of five study areas in the Nation selected for the Agricultural Chemicals: Sources, Transport, and Fate study by the Agricultural Chemicals Team (ACT) of the U.S. Geological Survey's National Water-Quality Assessment (NAWQA) Program (Capel and others, 2004). A primary goal of the ACT is to identify the natural and human factors affecting the transport and fate of agricultural chemicals in several environmental settings. To understand the sources, transport, and fate of agricultural chemicals on a watershed level, intensive chemical sampling was conducted in the Leary Weber Ditch Basin, which is nested within the Sugar Creek Basin (Erwin and others, 2003). Samples were collected from each environmental compartment within Leary Weber Ditch—precipitation, tile drains, overland flow, unsaturated zone, surface water, ground water, and the ground-water/surface-water interface.

Some of the natural factors and human influences affecting water quality in the Sugar Creek and Leary Weber Ditch Basins are described in this report. A comparison of the characteristics of the two basins, showing similarities and differences, is presented. These comparisons are a basis for the sampling design implemented for the study in the Sugar 
Creek and Leary Weber Ditch Basins during water years 2002 through 2004 and will serve as a context for the analysis and interpretation of results. The scope of this report is limited to a description of major natural (physiography, geology, soils, climate, and hydrology) and human (land and water use, population, and modifications to natural hydrology) components of the environmental setting. A brief description of the study design as applied to the Sugar Creek and Leary Weber Ditch Basins also is included.

\section{Environmental Setting}

Sugar Creek Basin drains $92.6 \mathrm{mi}^{2}$ in central Indiana (fig. 1). Within Sugar Creek Basin, Leary Weber Ditch drains $2.79 \mathrm{mi}^{2}$. Although the environmental settings with these basins are similar, there are differences in some characteristics. Leary Weber Ditch is a small basin in which natural characteristics essentially are homogenous. Sugar Creek, which encompasses a larger area, has a higher degree of heterogeneity.

Leary Weber Ditch is a small, intermittent stream $20 \mathrm{mi}$ east of Indianapolis in Hancock County. The ditch is characterized by a clay and muck bottom in its upstream segment, with a more cohesive sand and gravel bottom toward its mouth. It is primarily a tile-drain-fed creek. Most of the basin is surrounded by farmland, although the southernmost section is bordered by woodland. The town of Mohawk is $500 \mathrm{ft}$ to the southwest. Leary Weber Ditch flows $2.83 \mathrm{mi}$ from its source to its confluence with Sugar Creek.

The part of Sugar Creek included in this study spans three counties in central Indiana. Its source is northeast of Indianapolis in Henry County. As is the case with Leary Weber Ditch, the tributaries of Sugar Creek are primarily tile-drain fed. Sugar Creek is surrounded by farmland and flows near several small towns. Intermittently, woodlands and green spaces border Sugar Creek and several major roads cross it. The length of Sugar Creek is $41.4 \mathrm{mi}$ from its headwaters to the U.S. Geological Survey (USGS) streamflow-gaging station, Sugar Creek at New Palestine. Sugar Creek flows in a generally south-southwest direction to its confluence with the Big Blue River.

\section{Physiography}

The two basins have similar physiography. Both are completely contained within the New Castle Till Plains and Drainageways physiographic division in eastern Indiana (Gray, 2000). The revealing feature of this landscape is the number of tunnel valleys that cross in a south to southwest radial pattern (Gray, 2000). As described by Gray, this crossing pattern intersects an area of low plain that otherwise would be indistinguishable from surrounding areas. Topographically, there is a 240-ft range in elevation in Sugar Creek Basin and a 31-ft range in elevation in Leary Weber Ditch Basin (fig. 2).
The valley grades differ substantially-Leary Weber Ditch falls $10.95 \mathrm{ft} / \mathrm{mi}$, and Sugar Creek falls $5.80 \mathrm{ft} / \mathrm{mi}$ within the study area (U.S. Geological Survey, 1983).

\section{Geology}

Most of the Sugar Creek Basin and the entire Leary Weber Ditch Basin overlie a combination of Devonian limestone and dolomite bedrock from the Muscatatuck Group (fig. 3, table 1). The bedrock consists of 50 to $90 \mathrm{ft}$ of dolomite and limestone and small amounts of anhydrite and gypsum (Shaver and others, 1986; Gray and others, 1985). The remaining part of the Sugar Creek Basin is underlain by either Silurian dolomite and limestone or Ordovician shale. The Silurian dolomite and limestone bedrock comprises the Wabash and Pleasant Mills Formations, Salamonie Dolomite, Louisville Limestone, Cataract Formation, and the Brassfield Limestone. This bedrock, present as irregular outcrops throughout the basin, is made up of limestone, dolomite, dolomitic limestone, and minor amounts of shale and chert. The Silurian dolomite and limestone bedrock has a combined thickness of 90 to $500 \mathrm{ft}$ (Hasenmueller and Bassett, 1980). The Ordovician shale bedrock can be found near the source of Sugar Creek at the extreme northeastern part of the basin. It consists of the Whitewater Formation, thinly interbedded shale with limestone, that has an average thickness of more than $400 \mathrm{ft}$ (Fenelon and Greeman, 1994). Unconsolidated materials (sand and gravel) ranging from 0 to $400 \mathrm{ft}$ in thickness overlie much of the bedrock in the basins (fig. 4).

\section{Soils}

Soils in the study area are identified broadly as either loam or silt loam (fig. 5). Loam soils are high-clay content mixtures with silt and sand. These generally are found in and near drainages as a result of outwash of larger materials from the area. Conversely, silt loams are soils rich in clay that have a higher proportion of loose sedimentary particles. These commonly are found in flat regions and in areas not near drainages in the study area.

Three dominant soil associations are found in the Sugar Creek Basin. They are listed in order of their prevalence: Crosby-Brookston, Miami-Crosby, and Ockley-Sloan-Shoals. The Crosby-Brookston association is found on the broad, level uplands of the area. It is the predominant association in Hancock County (72.7 percent) (Ruesch, 1978). These soils are generally deep, very poorly drained to somewhat poorly drained, and of moderate fine-granular to mediumgranular texture. The surface layer consists of 9 to $12 \mathrm{in}$. of silty clay loam. Crosby-Brookston soils were formed from loamy glacial till or in loamy sediment and the underlying glacial till. Chances of surface erosion are negligible because runoff is low. Available water capacity is high. Natural fertility and organic matter are high to moderate (Ruesch, 1978). 


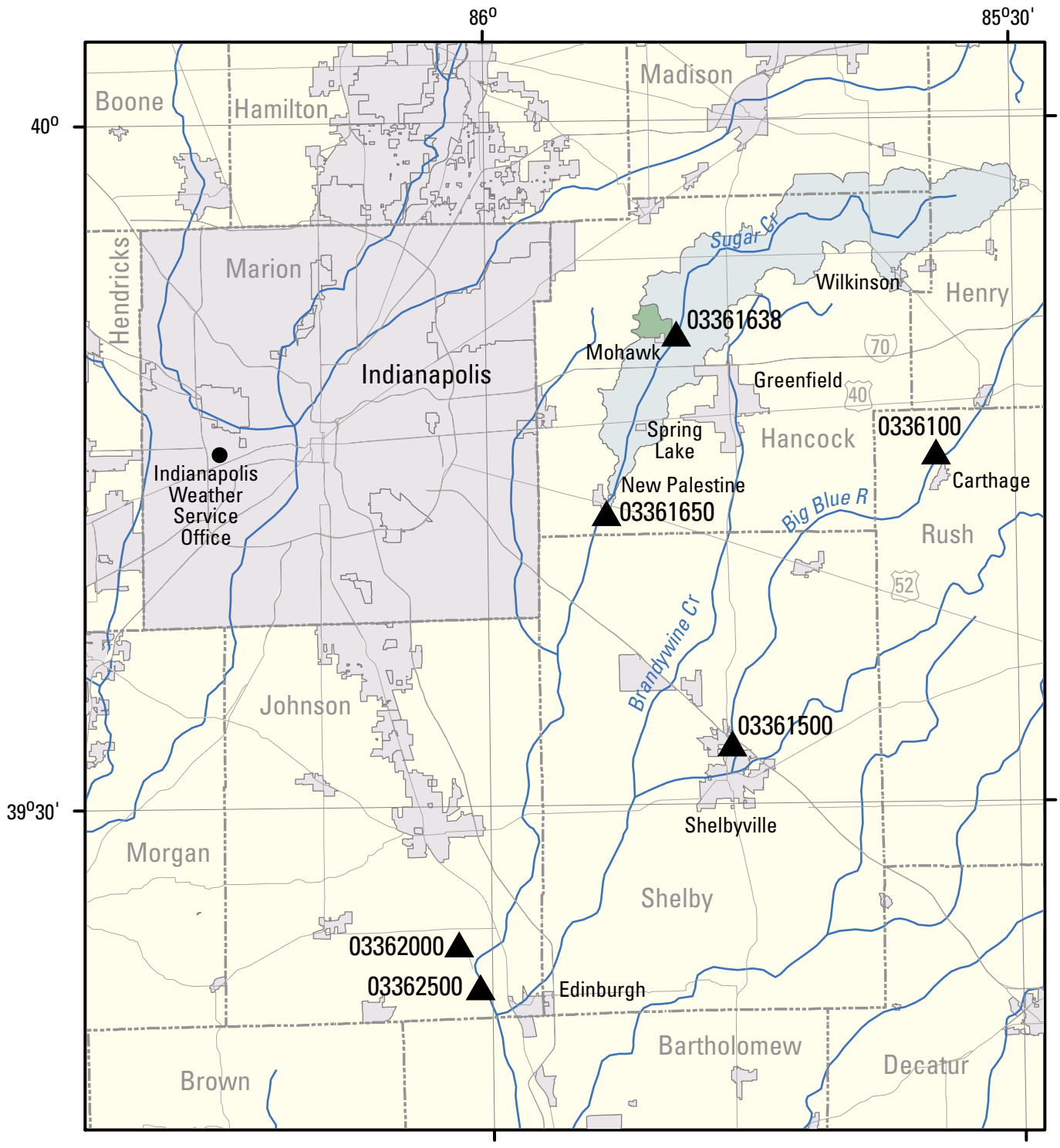

Base from U.S. Geological Survey digital data 1:100,000, 1983.

Universal Transverse Mercator projection,

Zone 16, North American Datum, 1983

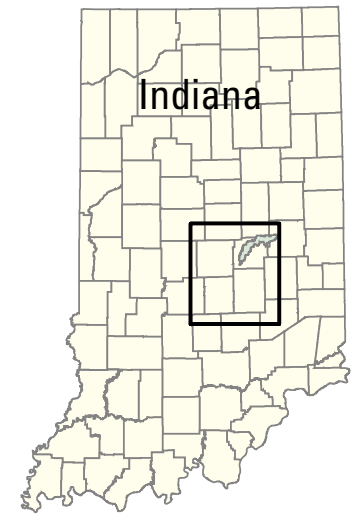

EXPLANATION

Cities and towns

Sugar Creek Basin

Leary Weber Ditch Basin

A U.S. Geological Survey streamflow-gaging station

County lines

Figure 1. Location of the Leary Weber Ditch and Sugar Creek Basins, Indiana. 


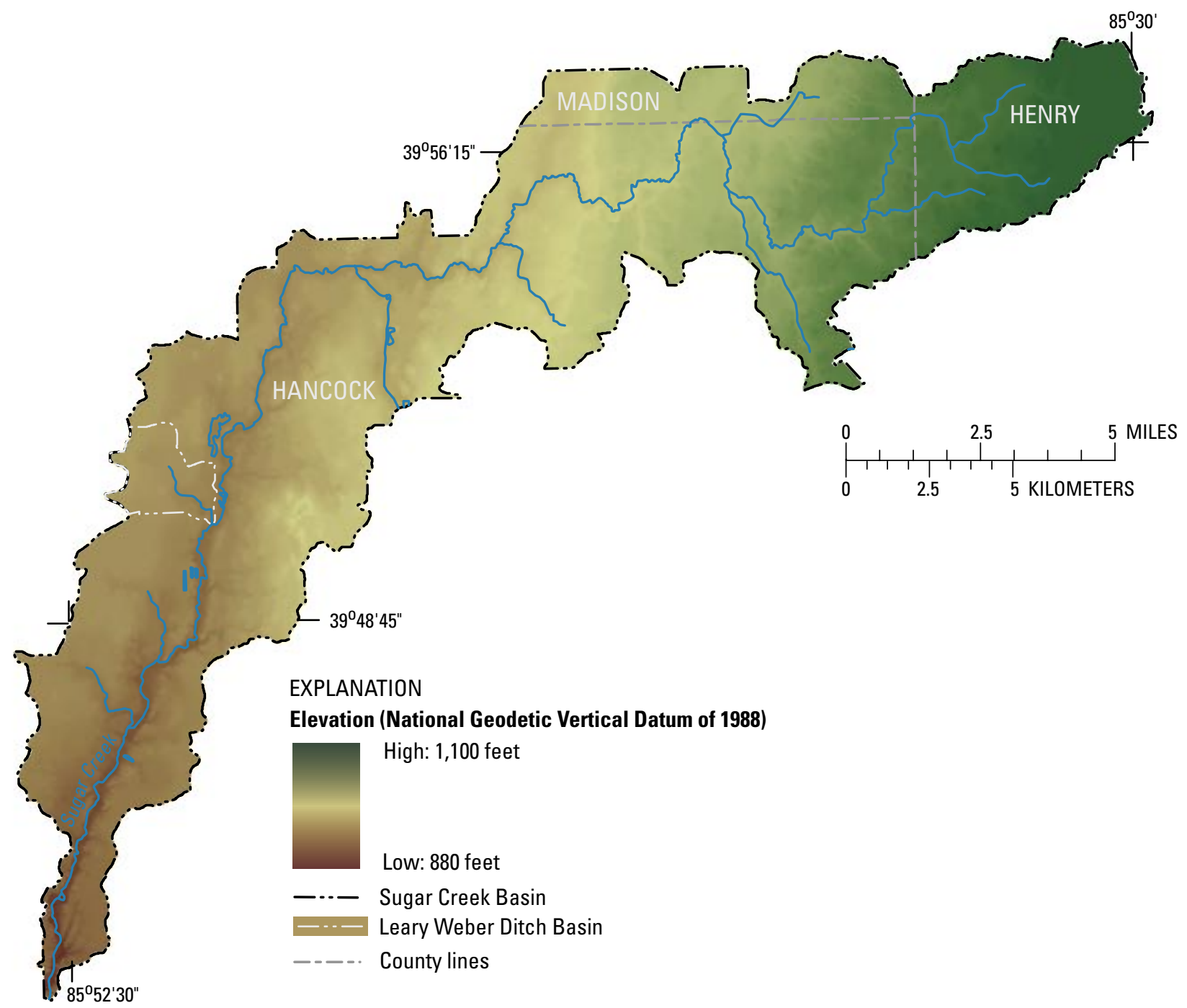

Base from U.S. Geological Survey digital data, 1:100,000, 1983. Universal Transverse Mercator projection,

Zone 16, North American Datum, 1983

Figure 2. Physiographic relief in the Leary Weber Ditch and Sugar Creek Basins, Indiana. 


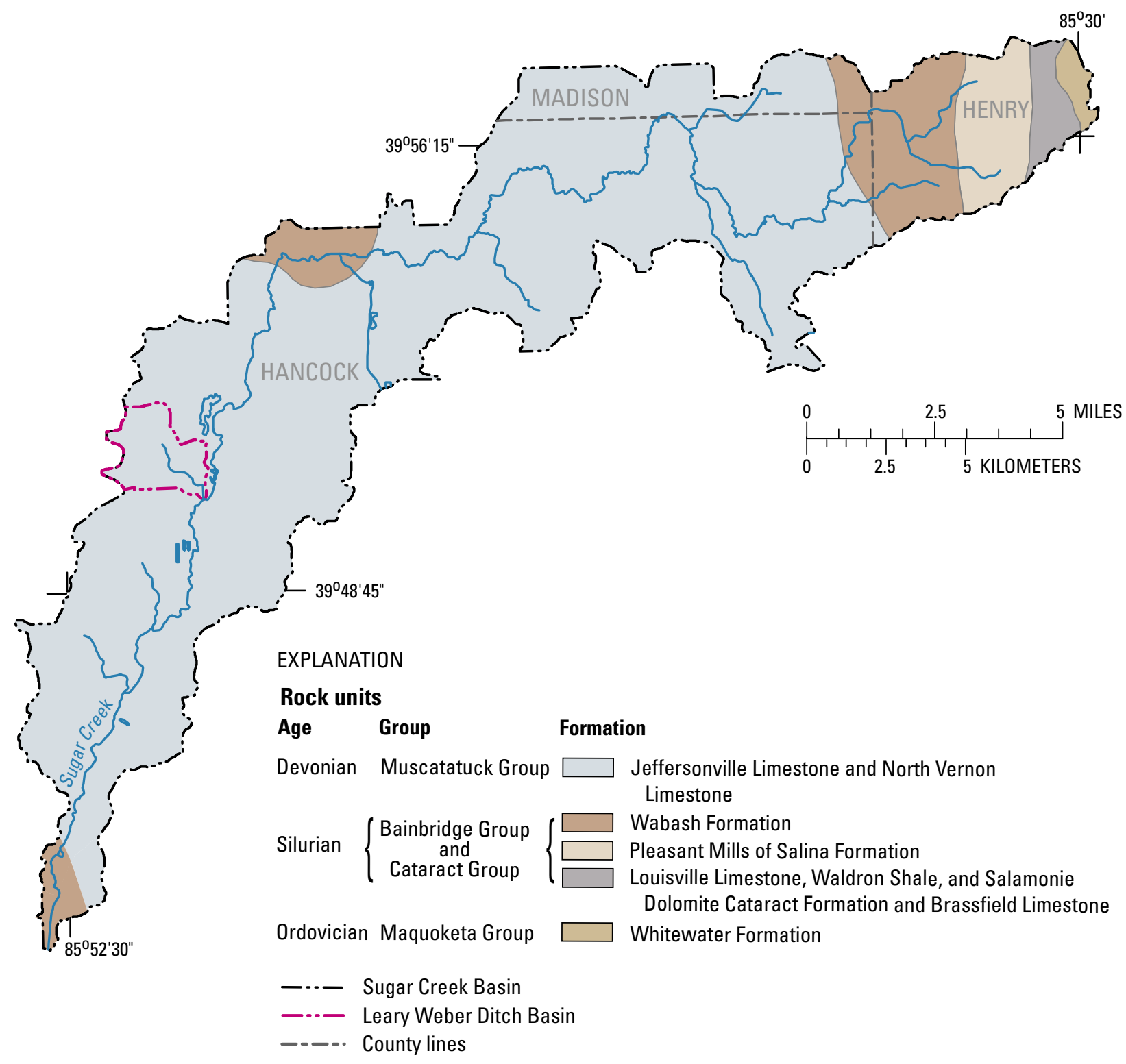

Base from U.S. Geological Survey digital data, 1:100,000, 1983.

Universal Transverse Mercator projection,

Zone 16, North American Datum, 1983

Figure 3. Generalized bedrock geology in the Leary Weber Ditch and Sugar Creek Basins, Indiana (Shaver and others, 1986; Gray and others, 1985). 
Table 1. Generalized stratigraphic column for the Leary Weber Ditch and Sugar Creek Basins, Indiana (Fenelon and Greeman, 1994; Clark, 1980; Schneider and Gray, 1966; Wayne, 1963).

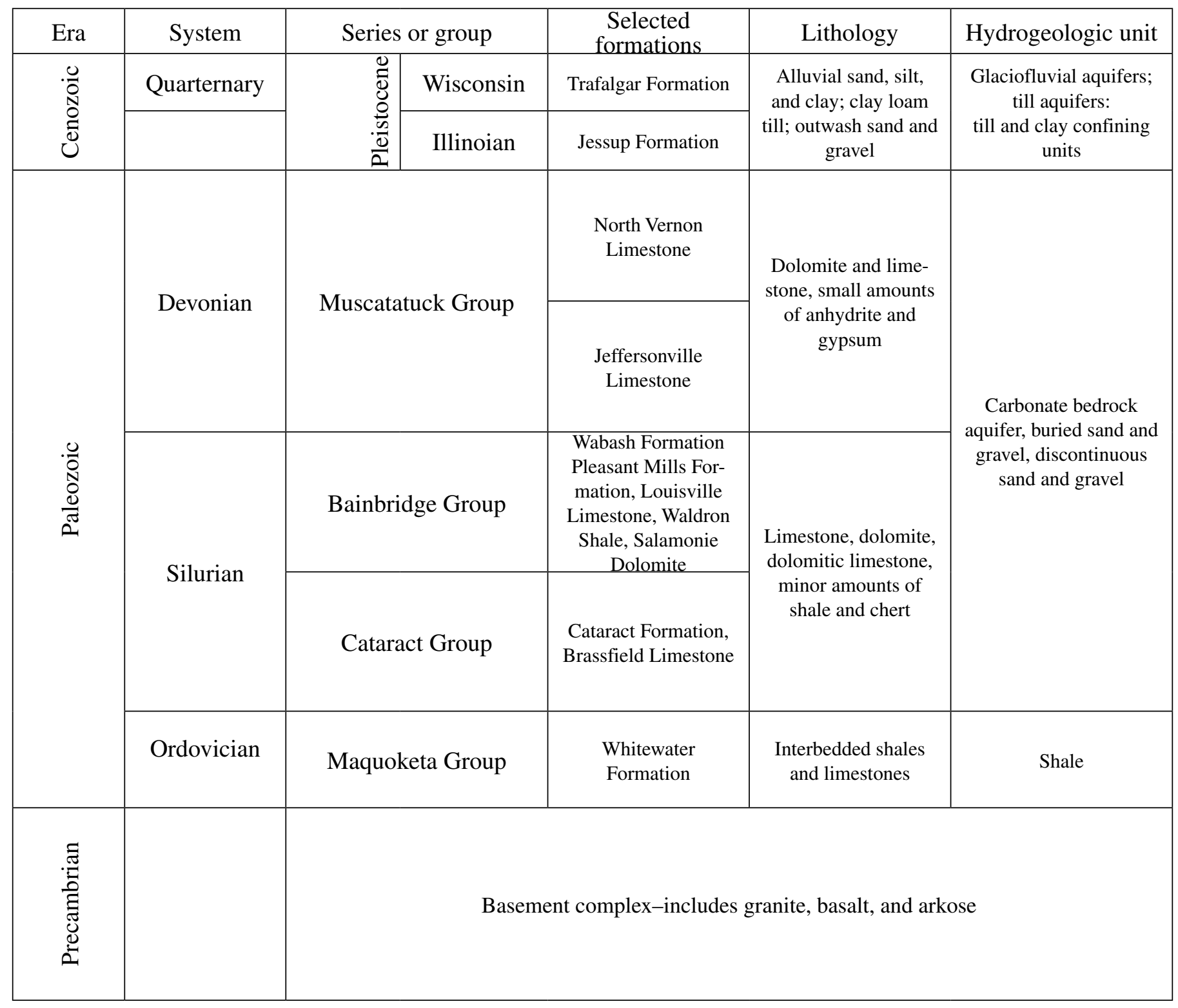



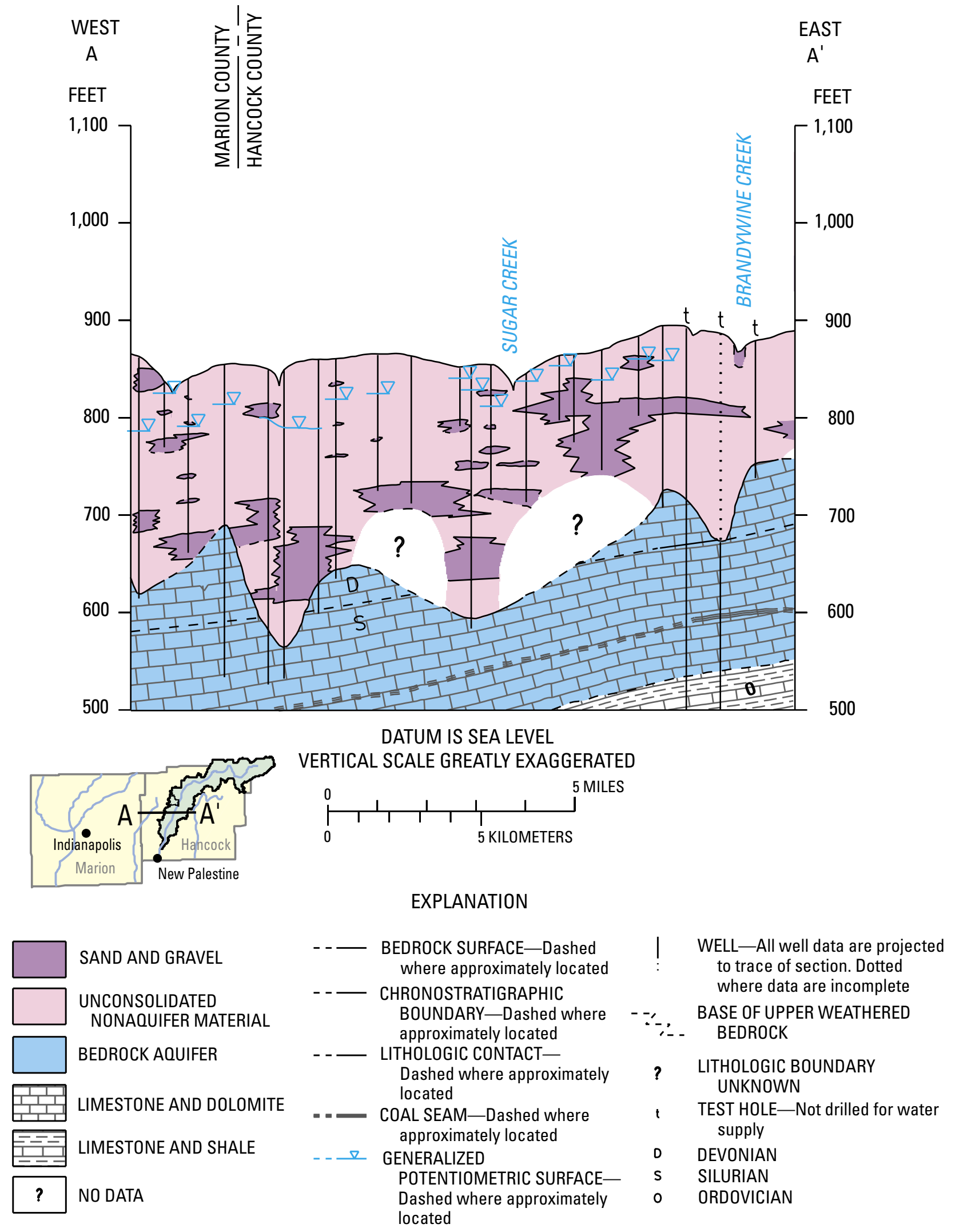

Figure 4. Cross section of geologic strata in the Leary Weber Ditch and Sugar Creek Basins, Indiana (Fenelon and Greeman, 1994). 


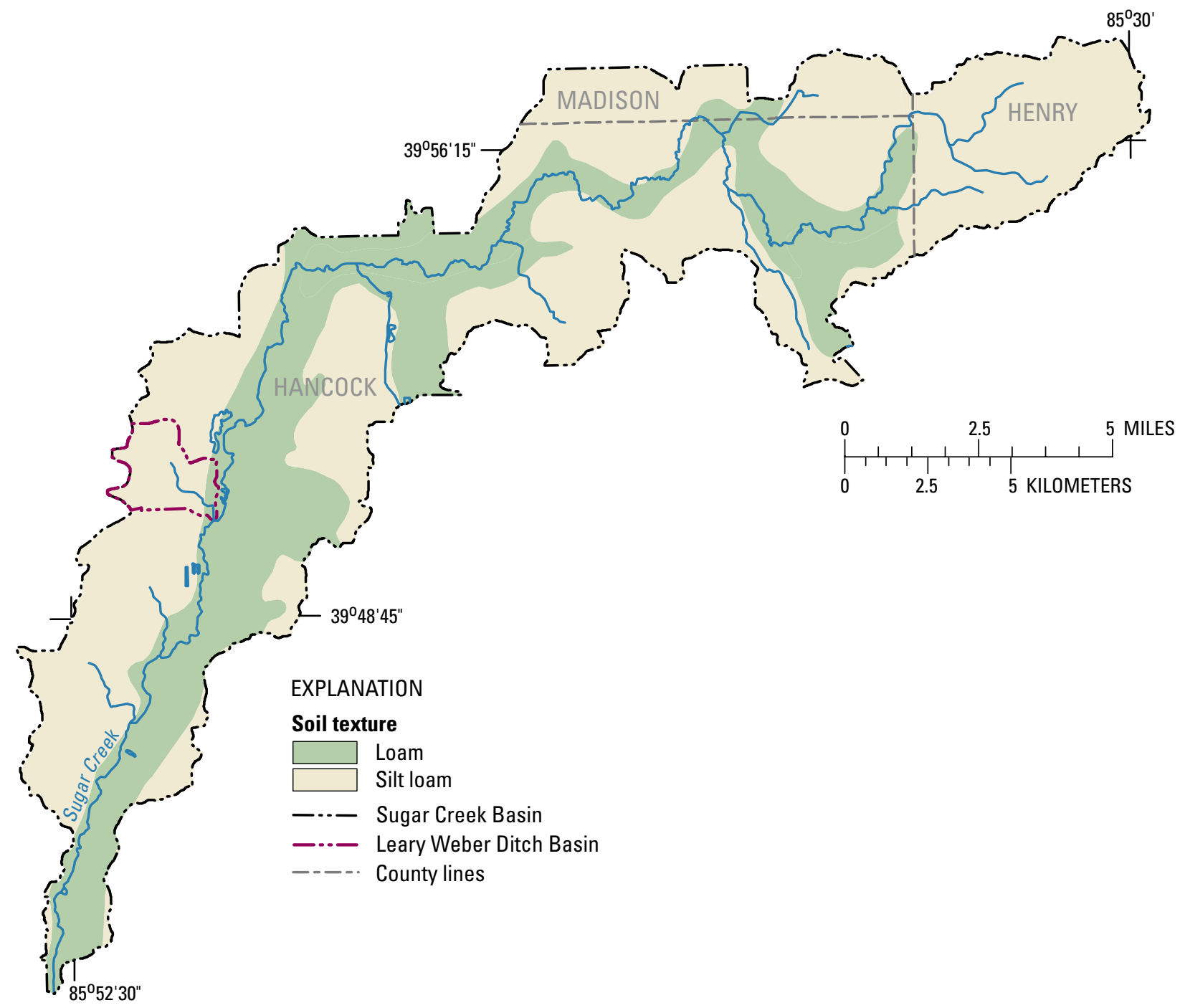

Base from U.S. Geological Survey digital data, 1:100,000, 1983.

Universal Transverse Mercator projection,

Zone 16, North American Datum, 1983

Figure 5. Generalized soil types in the Leary Weber Ditch and Sugar Creek Basins, Indiana (U.S. Department of Agriculture, Natural Resources Conservation Service, 1994). 
The Miami-Crosby association is found in the rolling uplands, the breaks between the uplands, and the bottom lands paralleling the major streams (Ruesch, 1978). These soils are deep, well drained to somewhat poorly drained, and mediumto-fine texture. The surface layer consists of 6 to 9 in. of silt loam. Miami-Crosby soils were formed in loamy glacial till. Chances of surface erosion are high. Available water capacity is high. Natural fertility and organic matter are moderate (Ruesch, 1978).

The Ockley-Sloan-Shoals association encompasses sloping river terraces, outwash plains, and nearly level bottom lands (Ruesch, 1978). These soils are deep, well drained to very poorly drained, and medium-to-fine texture. The surface layer consists of 8 to $13 \mathrm{in}$. of silt loams and silty clay loams. Ockley-Sloan-Shoals soils were formed in glacial outwash and alluvium. Chances of surface erosion are high. Poor soil drainage limits potential land use. Available water capacity is high. Natural fertility and organic matter are moderate to high (Ruesch, 1978).

The Leary Weber Ditch Basin consists primarily of soils of the Crosby-Brookston association. Miami-Crosby soils are found in lesser quantities near the ditch channel in the southern part of the basin. Ockley-Sloan-Shoals soils, often characterized by the presence of a sandy bottom, are found in the Leary Weber Ditch channel near the USGS streamflowgaging station and downstream to its confluence with Sugar Creek. Most soils in the basin are poorly drained to very poorly drained.

The soil associations in both basins are suited naturally to row-crop agriculture and also would be suitable for growing grasses, legumes, and special crops such as tomatoes. These soils produce well under good management. They must be tilled when moisture conditions are right to prevent the formation of large soil clods that complicate planting and seed germination. Successful farming in these soils requires lowering the water table, removing ponded water, enhancing fertility, and ensuring consistent soil tilth (Ruesch, 1978).

\section{Land and Chemical Use}

Agriculture is the main land use in the study area (fig. 6). In the Sugar Creek Basin, 75 percent of the land is used for row-crop production (table 2). Acreage is divided nearly equally between corn and soybeans. Similarly, in the Leary Weber Ditch Basin, 87 percent of the total basin is used for row crops. During 2004, most of the crops harvested were soybeans (47 percent) and corn (39 percent) ${ }^{1}$. Other agricultural land uses in the study area include pasture and growing small grains.

Farmers employ a wide range of chemicals to promote plant growth and to inhibit vegetative competition (table 3 ). The most-widely used growth enhancer applied in the study

${ }^{1}$ Estimate made on basis of surveys of farmers in 2003 and 2004. area is nitrogen, which is applied to nearly all of the corn crop in the study area. Nitrogen can be applied either as a pre- or post-emergent. Crops with inadequate nitrogen levels produce poor yields and are commonly low in protein (Trautmann and others, 2005). In 2003, the most prevalent form of nitrogen applied in the Leary Weber Ditch Basin was anhydrous ammonia.

Glyphosate is the most-widely used chemical herbicide applied to soybeans. It is a broad-spectrum, systemic growth regulator that is used to control annuals and perennials. Glyphosate eliminates a plant's ability to form aromatic amino acids that are necessary for protein synthesis, thus killing the plant within 3 days (Information Ventures, Inc., 1995). Genetically engineered soybeans are unaffected by glyphosate. Most of the plants that compete with soybeans for nutrients, light, and moisture are destroyed by glyphosate. In 2003, an estimated 26,500 lb of glyphosate were applied to 22,600 acres in the Sugar Creek Basin (Indiana Agricultural Statistics Service, 2004). Of all soybean fields planted in the study area, 97 percent were treated with glyphosate.

Atrazine is the most-widely used herbicide on corn. It controls broadleaf and grassy weeds competing for light, nutrients, and water in and around corn fields. Atrazine is absorbed in the roots and through the leaves of plants and then transported through the plant to the buds and other active-growth areas. After sufficient accumulation in susceptible species, atrazine inhibits photosynthesis, killing the plant. In plants that are not susceptible, atrazine is metabolized (Cornell University, 2005b). In 2003, an estimated 22,200 lb of atrazine were applied to 17,800 acres in the Sugar Creek Basin (Indiana Agricultural Statistics Service, 2004).

Chlorpyrifos is a broad-spectrum, synthetic-chemical insecticide. It is effective for controlling a variety of insects, including cutworms, rootworms, cockroaches, fleas, ticks, grubs, beetles, and flies (Cornell University, 2005a). Insecticides are applied only to approximately 10 percent of the study area (Indiana Agricultural Statistics Service, 2004).

Irrigation and manure application in the study basins are minimal. Water supply for crop growth comes primarily from rainfall. Manure was applied to only about 2 percent of the row-crop area in Hancock County in 2002 (U.S. Department of Agriculture, 2002). Typically, fields with manure applications are owned by or located near dairy or swine operations.

\section{Population}

The population of the Sugar Creek Basin is spread over a wide area (fig. 7). There are no large cities within the basin; most residents live in small communities or rural areas. Towns in the basin include Spring Lake (population about 300) and Wilkinson (population about 400) (U.S. Census Bureau, 2000). Population density ranges from less than 300 people $/ \mathrm{mi}^{2}$ in the northern part of the Sugar Creek Basin to greater than 1,000 people $/ \mathrm{mi}^{2}$ in the southern part 


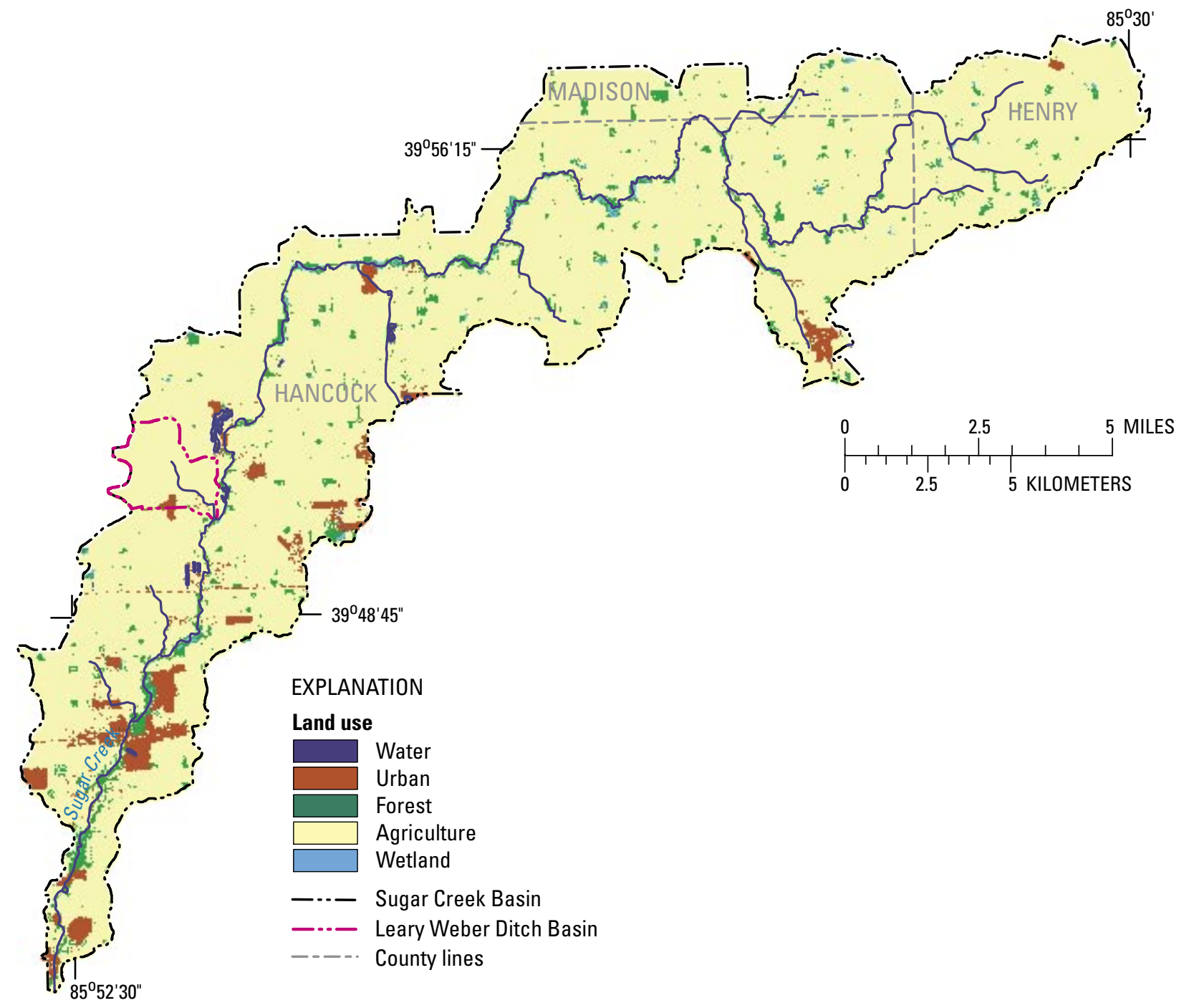

Base from U.S. Geological Survey digital data, 1:100,000, 1983.

Universal Transverse Mercator projection,

Zone 16, North American Datum, 1983

Figure 6. Land use in the Leary Weber Ditch and Sugar Creek Basins, Indiana (U.S. Geological Survey, 2000). 
Table 2. Summary of land use and land cover in the Leary Weber Ditch and Sugar Creek Basins, Indiana.

$[--$, No data $]$

\begin{tabular}{|c|c|c|c|c|c|c|}
\hline $\begin{array}{l}\text { Land } \\
\text { cover }\end{array}$ & $\begin{array}{c}\text { Area } \\
\text { (acres) }\end{array}$ & $\begin{array}{c}\text { Percent of } \\
\text { agricultural land }\end{array}$ & $\begin{array}{c}\text { Percent of } \\
\text { total watershed area }\end{array}$ & $\begin{array}{c}\text { Area } \\
\text { (acres) }\end{array}$ & $\begin{array}{l}\text { Percent of } \\
\text { agricultural land }\end{array}$ & $\begin{array}{c}\text { Percent of } \\
\text { total watershed area }\end{array}$ \\
\hline Corn & 21,900 & 45 & 36 & 705 & 42 & 39 \\
\hline Soybeans & 23,400 & 47 & 39 & 845 & 51 & 47 \\
\hline Small grains & 1,500 & 3 & 3 & 0 & 0 & 0 \\
\hline Pasture & 2,460 & 5 & 4 & 111 & 7 & 6 \\
\hline
\end{tabular}

Table 3. Summary of estimated herbicide, insecticide, and fertilizer use in the Leary Weber Ditch and Sugar Creek Basins, Indiana.

[lb, pound; data derived from aerial photos, 2003; National Agricultural Imagery Program, 2003; farmer surveys, 2003-04; and Indiana Agricultural Statistics Service, 2004]

\begin{tabular}{|c|c|c|c|c|c|c|}
\hline \multirow[b]{2}{*}{ Chemical } & \multirow[b]{2}{*}{$\begin{array}{l}\text { Crops } \\
\text { treated }\end{array}$} & \multirow[b]{2}{*}{$\begin{array}{l}\text { Application } \\
\text { period }\end{array}$} & \multicolumn{2}{|c|}{$\begin{array}{c}\text { Sugar Creek } \\
\text { (Iarge stream) }\end{array}$} & \multicolumn{2}{|c|}{$\begin{array}{l}\text { Leary Weber Ditch } \\
\text { (small stream) }\end{array}$} \\
\hline & & & $\begin{array}{c}\text { Area of } \\
\text { application } \\
\text { (acres) }\end{array}$ & $\begin{array}{l}\text { Total mass } \\
\text { (Ib) }\end{array}$ & $\begin{array}{c}\text { Area of } \\
\text { application } \\
\text { (acres) }\end{array}$ & $\begin{array}{l}\text { Total mass } \\
\text { (lb) }\end{array}$ \\
\hline \multicolumn{7}{|l|}{ Herbicides } \\
\hline Acetochlor & Corn & Pre-emergence & 7,070 & 13,900 & 436 & 209 \\
\hline Atrazine & Corn & Pre- or post-emergence & 17,800 & 22,200 & 679 & 821 \\
\hline Glyphosate & Soybeans & Pre- or post-emergence & 22,600 & 26,500 & 1,020 & 1,240 \\
\hline Metolachlor & Corn & Pre-emergence & 4,720 & 6,220 & 274 & 79 \\
\hline \multicolumn{7}{|l|}{ Insecticides } \\
\hline Chlorpyrifos & Corn & Pre- or post-emergence & 1,930 & 2,330 & 703 & 3,770 \\
\hline Tefluthrin & Corn & Pre-emergence & 3,220 & 353 & 274 & 4 \\
\hline \multicolumn{7}{|l|}{ Fertilizer } \\
\hline Nitrogen & Corn & Pre- or post-emergence & 21,200 & $3,180,000$ & 703 & 105,000 \\
\hline Phosphate & Corn & Pre-emergence & 18,200 & $1,400,000$ & 274 & 18,300 \\
\hline Potash & Corn & Pre-emergence & 17,800 & $2,350,000$ & 274 & 30,100 \\
\hline
\end{tabular}




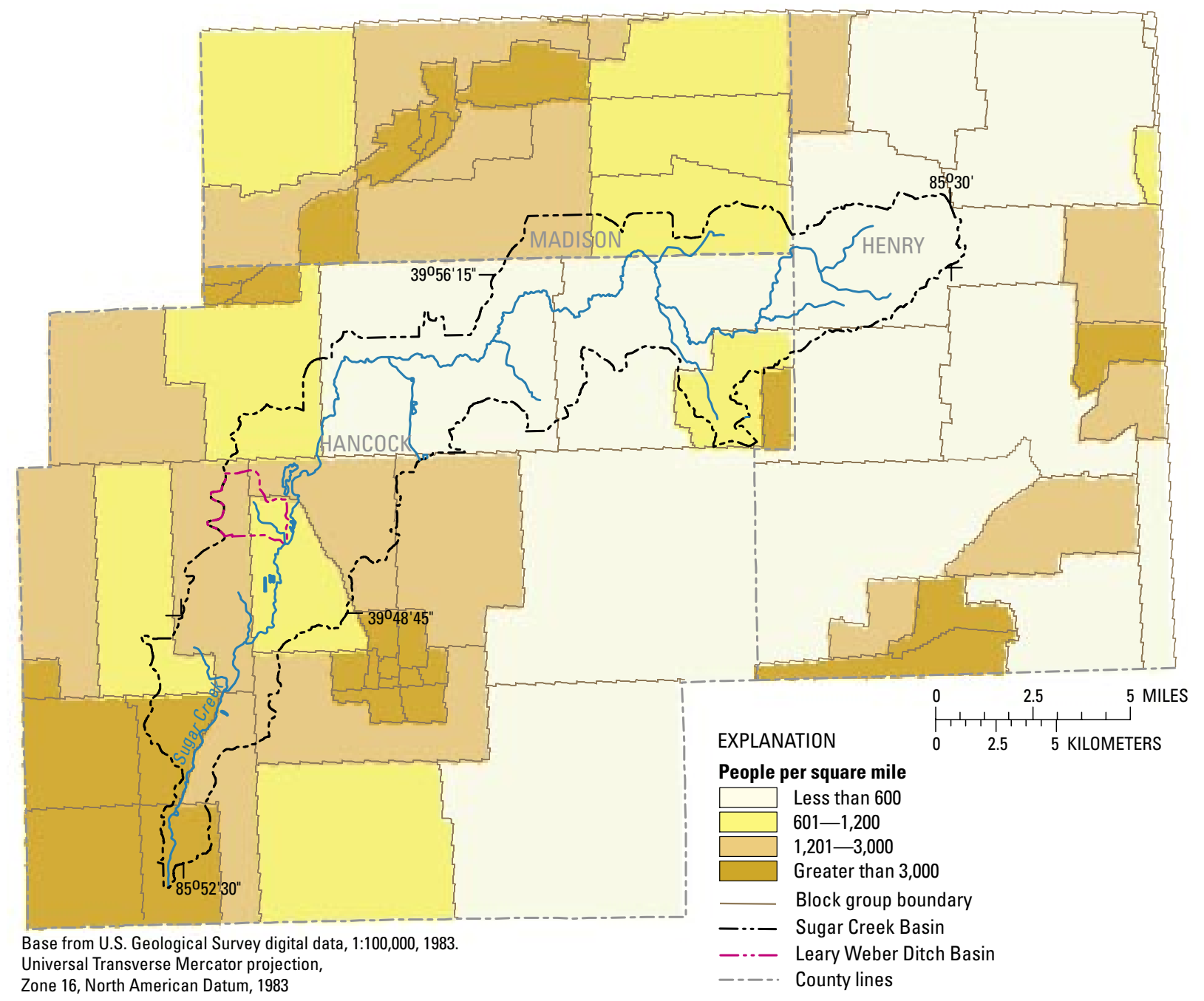

Figure 7. Population density by U.S. Census block group in the Leary Weber Ditch and Sugar Creek Basins, Indiana, 2000 (U.S. Census Bureau, 2000).

(U.S. Census Bureau, 2000). Recent suburban developments in the New Palestine area have increased the population in the lower third of the basin.

In the Leary Weber Ditch Basin, the population is estimated at less than 250 residents. Most live in single, rural homes on the edge of row-crop fields. Part of the town of Mohawk is within the basin's boundaries, providing a small population center. In the early 1800 s, few people lived in the study area; the 1820 census officially listed the population of Hancock County as zero (Geolytics, Inc., 2000). Over the last 185 years, the population of the county has grown to approximately 61,000 (Geolytics, Inc., 2000) (fig. 8). Most of this growth has not been within the study area. The population in both basins is increasing steadily, however. In the last 50 years, population increases are a direct result of improvements to roads and transportation, allowing people the opportunity to live farther from their place of work. In 2003, nearly
50 percent of Hancock County residents commuted to another county to work (Indiana Business Research Center, 2005).

The Hancock County part of the study area is within $24 \mathrm{mi}$ of Indianapolis.

\section{Climate}

Temperatures in the Sugar Creek and Leary Weber Ditch Basins are moderate, ranging from a mean of $74.9^{\circ} \mathrm{F}$ in July to a mean of $25.2^{\circ} \mathrm{F}$ in January (National Weather Service Forecast Office, 2005). Temperatures recorded during the study period (water years 2003 and 2004) exhibited similar ranges (fig. 9). More-extreme temperatures are also possible.

\footnotetext{
${ }^{2} \mathrm{~A}$ water year is the 12 -month period, October 1 through September 30.
} 


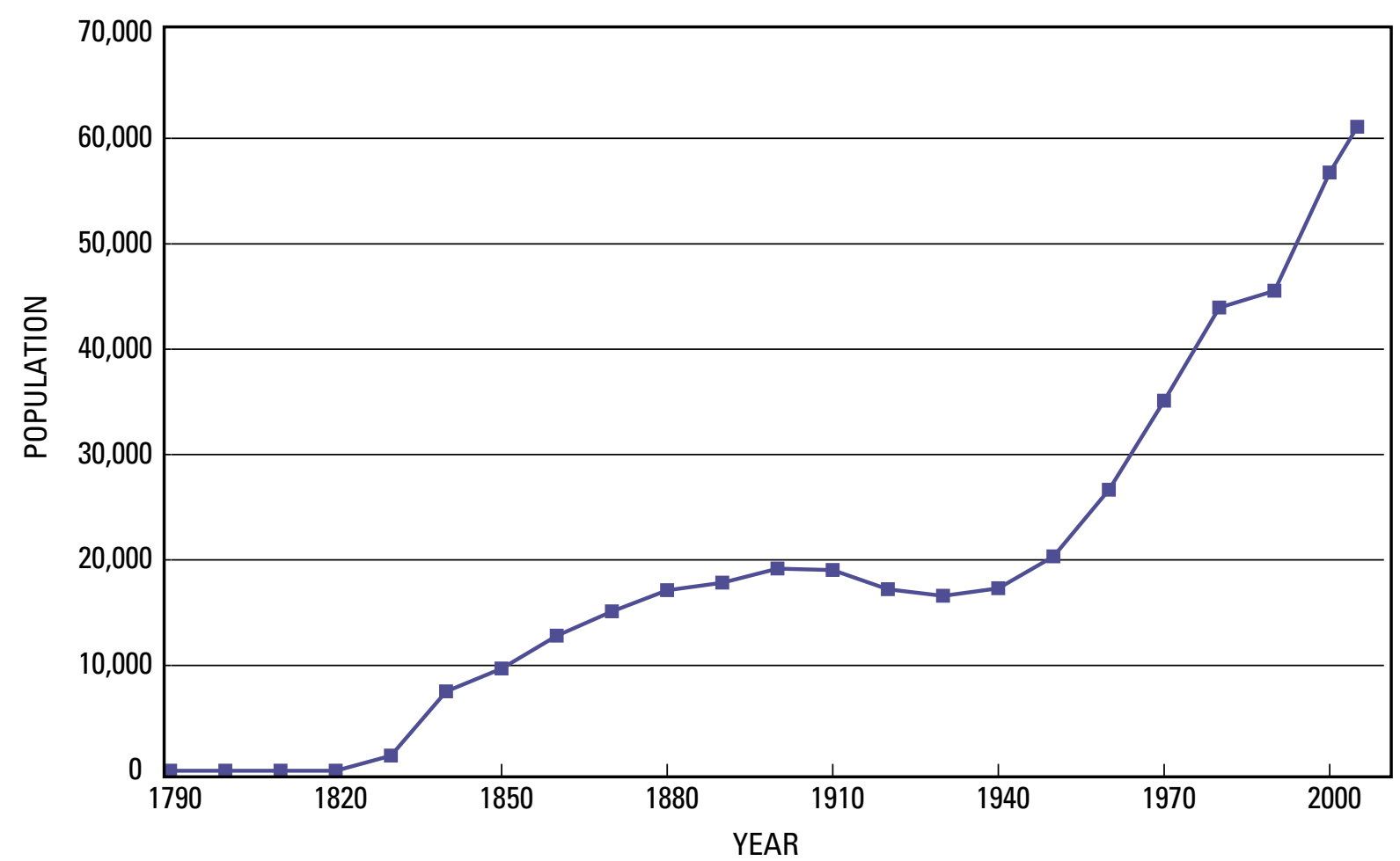

Figure 8. Population growth in Hancock County, Indiana, 1790 to 2005 (Geolytics, Inc., 2000).

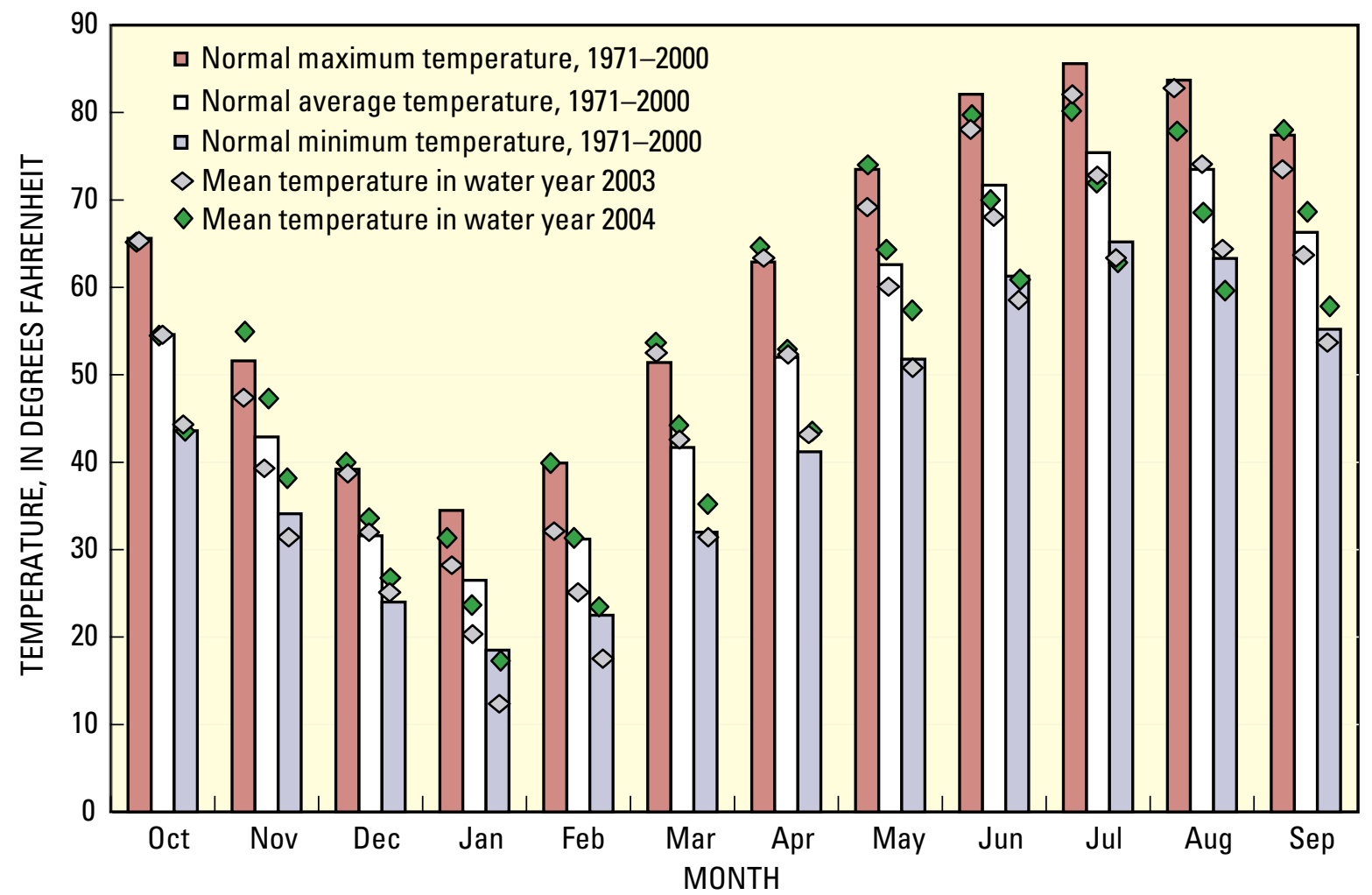

Figure 9. Normal monthly temperatures and monthly mean temperatures during water years 2003 and 2004 in the Sugar Creek Basin, Indiana (National Weather Service Forecast Office, 2005; Purdue University Applied Meteorology Group, 2005a). 
On average, 17 days per year have temperatures above $90^{\circ} \mathrm{F}$ and 115 days per year have temperatures below freezing (City Rating.com, 2002). The record high, observed at nearby Indianapolis, was $107^{\circ} \mathrm{F}$ on July 25,1934 . The lowest temperature ever recorded at Indianapolis was $-27^{\circ} \mathrm{F}$ on January 19, 1994 (National Weather Service Forecast Office, 2005).

Mean annual precipitation in Indianapolis is $39.5 \mathrm{in}$.; however, annual precipitation totals vary widely (fig. 10) (National Climatic Data Center, 2004). Total precipitation during 2003 (52.4 in.) was 25 percent more than the long-term average. In 2004, total precipitation (48.8 in.) was 20 percent more than the long-term average. The record-high annual precipitation at nearby Indianapolis was 57.65 in. in 1876; the record-low annual precipitation was 24.97 in. in 1934 (National Weather Service Forecast Office, 2005). Generally, annual precipitation is distributed evenly throughout the year, with total amounts in spring and early summer exceeding those of winter. Occasionally, heavy spring rains delay crop planting. During this study, large deviations from normal monthly precipitation levels were evident (fig. 10). In water year 2003, 10.6 in. of rain fell in September. In water year 2004, the month with the highest rainfall was May (8.55 in.). During the study period, there were several months with lower-than-average precipitation levels. In March 2003, only 8 percent of precipitation fell (as compared to the historical average). February, April, and September 2004 were drier than the long-time normal.

Evapotranspiration, a combination of evaporation and transpiration, plays a major role in the water budget of both basins. In Indiana, evapotranspiration accounts for an average of 25 to 30 in. of moisture loss each year (U.S. Geological Survey, 1990). Factors affecting evapotranspiration include wind speed, solar radiation, reflective characteristics of the land surface, and seasonal variation such as changes in temperature. Evapotranspiration affects streamflow in the low-flow period, July through October.

\section{Hydrology}

The hydrology of the Leary Weber Ditch and Sugar Creek Basins is described in the following sections by characterizing surface- and ground-water flow. Periods of drought and flooding are recounted to present a historical picture of extreme conditions in the study area. Manmade modifications to the natural hydrology affect flow conditions and water quality, thereby altering natural processes.

\section{Surface Water}

Discharge data are collected by the USGS at two streamflow-gaging stations in the study area: station 03361638, Leary Weber Ditch at Mohawk, IN, and station 03361650, Sugar Creek at New Palestine, IN (fig. 11). The gaging station on Leary Weber Ditch is approximately 0.32 stream mile upstream from its confluence with Sugar Creek. The gaging station on Sugar Creek is near the bottom of the Sugar Creek Basin as defined in this study, approximately 11 stream miles downstream from the mouth of Leary Weber Ditch. The gaging station on Sugar Creek is $1.1 \mathrm{mi}$ below the Sugar Creek Indicator site. Therefore, an additional $1.3 \mathrm{mi}^{2}$ of basin runoff are measured by the gaging station but are not sampled for water quality.

Mean daily discharge values for the Sugar Creek Basin are summarized for water years 1968 through 2004 (table 4). Discharge data for Leary Weber Ditch include only water years 2003 and 2004. In this table, flow-duration analyses of mean daily discharge are summarized and the percentage of time that a particular value of mean daily streamflow was exceeded or equalled is shown. High flows are indicated by the 1-percent flow durations. Low flows are indicated in the 90-percent flow-duration column. Therefore, the listed values of mean daily streamflow were exceeded 90 percent of the time at the respective gaging stations. Ground-water inflows are the primary source of stream base flow (Todd, 1980). Dividing the 90-percent flow-duration discharge by the drainage area indicates which bodies of water have the largest ground-water inputs. At base flow, there is little to no ground-water input into Leary Weber Ditch, but Sugar Creek's base flow comes almost entirely from ground water. As shown in table 4, however, the flow of Sugar Creek is made of low amounts of ground water, compared to nearby streams. Streams in nearby basins have as much as four times the ground-water input as do streams in the Sugar Creek Basin.

The mean annual discharge for Sugar Creek at New Palestine, IN, is 75,400 acre-ft. Streamflow for water years 2003 and 2004 was greater than the long-term average (fig. 12). From 1994 through 2004, 6 years have had annual flows greater than the average annual discharge.

Sugar Creek is a perennial stream. Mean daily streamflow for Sugar Creek at New Palestine, IN, is $102.6 \mathrm{ft}^{3} / \mathrm{s}$. Normally, higher flows start in late winter and continue through early summer (fig. 13). Snowmelt and the frequency of precipitation affect these higher streamflows. Lower flows occur from July through October from evapotranspiration and plant uptake. During water years 2003 and 2004, discharge was within historical ranges. With the exception of March and May in water year 2003, Sugar Creek had slightly lower flows than average during the winter through early summer. Higher-than-normal flows were recorded during later summer and fall, with the exception of August. Streamflow in water year 2004 continued the trend of higher flows into winter. For the remainder of the year, with the exception of late May and June, flows were low.

During water years 2003 and 2004, the mean daily streamflow for Leary Weber Ditch was $3.35 \mathrm{ft}^{3} / \mathrm{s}$. Streamflow patterns at Leary Weber Ditch are similar to those at Sugar Creek (fig. 13). Because of its much smaller drainage basin, the discharge from Leary Weber Ditch is only a fraction of that at Sugar Creek. Streamflows caused by precipitation are visible in the graph and decrease quickly after the cessation of rainfall. In water years 2003 and 2004, Leary Weber Ditch 

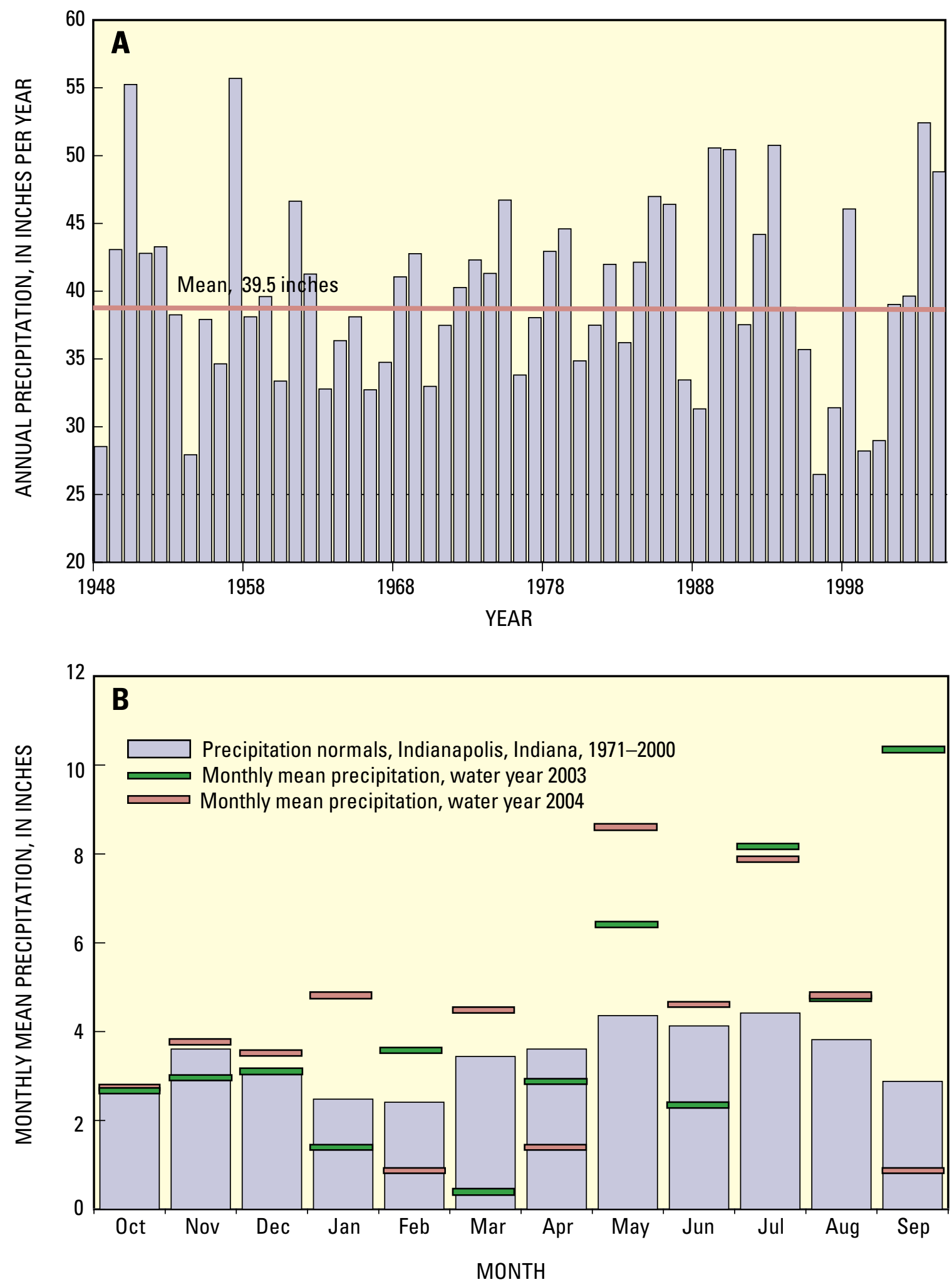

Figure 10. Precipitation in the Sugar Creek Basin, Indiana. A, annual precipitation, 1948-2004 (National Climatic Data Center, 2004; Purdue University Applied Meteorology Group, 2005b), and B, monthly mean precipitation for water years 2003 and 2004 and at Indianapolis, Indiana, 1971-2000 (National Climatic Data Center, 2004). 


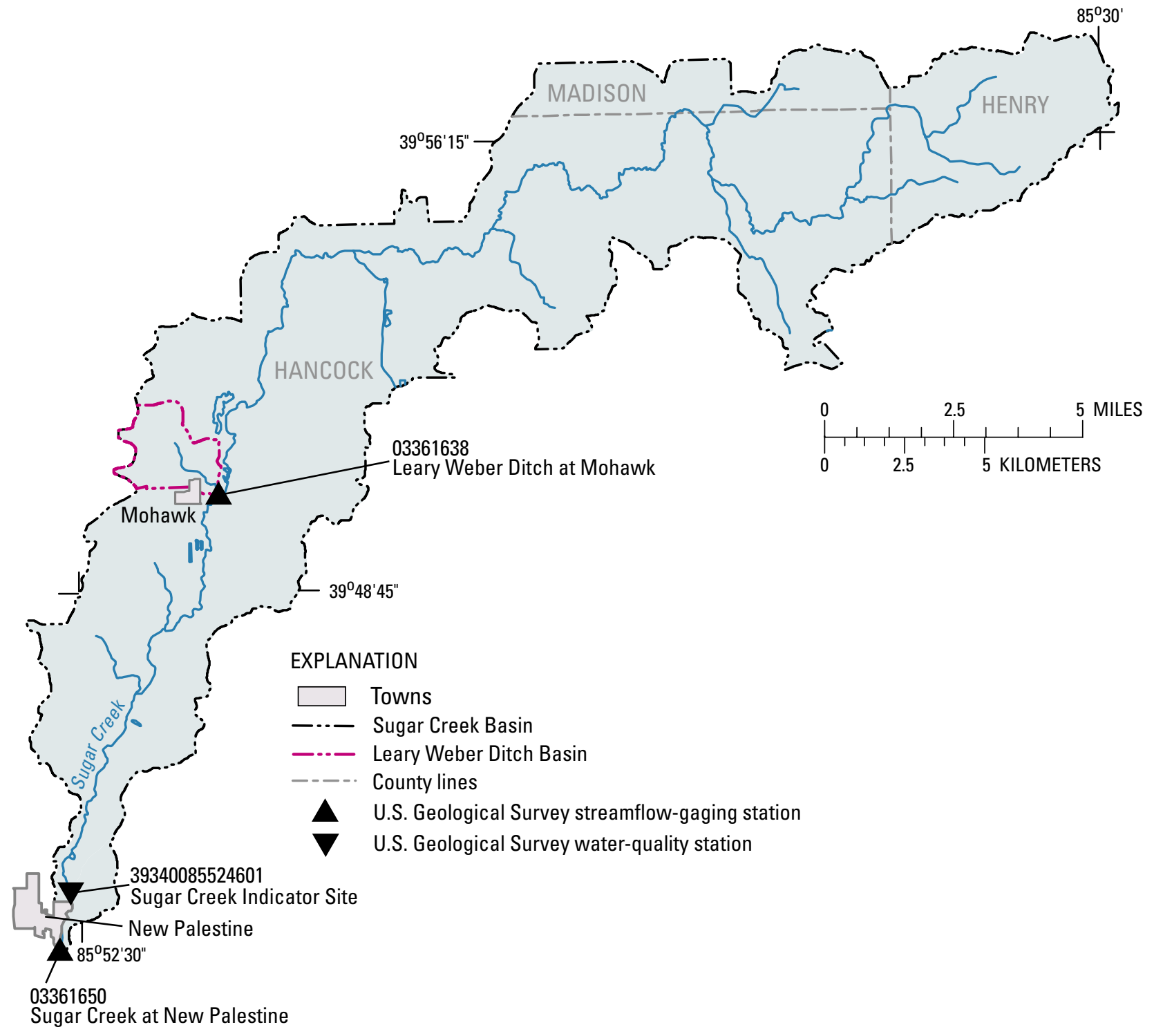

Base from U.S. Geological Survey digital data, 1:100,000, 1983. Universal Transverse Mercator projection,

Zone 16, North American Datum, 1983

Figure 11. Location of U.S. Geological Survey water-quality and streamflow-gaging stations in the Leary Weber Ditch and Sugar Creek Basins, Indiana. 
Table 4. Summary of mean daily discharge characteristics at selected U.S. Geological Survey streamflow-gaging stations in the Leary Weber Ditch and Sugar Creek Basins, Indiana (period of record for Leary Weber Ditch: 2003 and 2004; all other sites: 1968 through 2004).

$\left[\mathrm{mi}^{2}\right.$, square mile; $\mathrm{ft}^{3} / \mathrm{s}$, cubic foot per second; $\mathrm{ft}^{3} / \mathrm{s} / \mathrm{mi}^{2}$, cubic foot per second per square mile]

\begin{tabular}{|c|c|c|c|c|c|c|c|c|c|}
\hline \multirow[t]{2}{*}{ Station name } & \multirow{2}{*}{$\begin{array}{l}\text { Drainage } \\
\text { area } \\
\left(\mathrm{mi}^{2}\right)\end{array}$} & \multicolumn{7}{|c|}{$\begin{array}{l}\text { Percentage of time } \\
\text { mean daily discharge was greater than or equal to value shown } \\
\qquad\left(\mathrm{ft}^{3} / \mathrm{s}\right)\end{array}$} & \multirow{2}{*}{$\begin{array}{l}\text { Normalized } \\
90 \text { percent } \\
\left(\mathrm{ft}^{3} / \mathrm{s} / \mathrm{mi}^{2}\right)\end{array}$} \\
\hline & & 95 & 90 & 75 & 50 & 25 & 5 & 1 & \\
\hline $\begin{array}{l}\text { Sugar Creek at County Road } 400 \mathrm{~S} \text { at } \\
\text { New Palestine, IN } \\
03361650\end{array}$ & 93.9 & 4.9 & 7.2 & 18.4 & 48.9 & 111.0 & 421.0 & $1,010.0$ & .08 \\
\hline $\begin{array}{l}\text { Big Blue River at Carthage, IN } \\
03361000\end{array}$ & 184.0 & 49.5 & 58.2 & 80.0 & 131.0 & 226.0 & 624.0 & $1,590.0$ & .31 \\
\hline $\begin{array}{l}\text { Big Blue River at Shelbyville, IN } \\
03361500\end{array}$ & 421.0 & 72.5 & 88.7 & 149.0 & 283.0 & 533.0 & $1,620.0$ & $4,010.0$ & .21 \\
\hline
\end{tabular}

was dry during periods in summer and fall. During 2003, there were 97 days of no flow. During 2004, there were 73 days of no flow.

In Hancock County, residents do not use surface water for drinking water; it is used for other purposes though. In 2002, $0.3 \mathrm{Mgal} / \mathrm{d}$ of surface water were used in Hancock County. Surface-water uses include livestock $(0.05 \mathrm{Mgal} / \mathrm{d})$, industry (0.24 Mgal/d), and irrigation (0.01 Mgal/d) (U.S. Geological Survey, 2004).

\section{Ground Water}

Four major types of aquifers underlie the study area (table 5). The surficial sand and gravel aquifers and buried sand and gravel aquifers are used most often for water supply (Fenelon and Greeman, 1994). Surficial sand and gravel aquifers usually are adjacent to major drainages and are present near Sugar Creek in the southern part of the basin. They generally are found 10 to $40 \mathrm{ft}$ below land surface. Surficial sand and gravel aquifers frequently are used for water supply because of their high yield and recovery rates. Where surficial sand and gravel aquifers are not present, buried sand and gravel aquifers are found throughout most of the study area.
Buried sand and gravel aquifers are found at different horizons in the drift and often are covered by more than $10 \mathrm{ft}$ of nonaquifer materials (Fenelon and Greeman, 1994). High yields make these aquifers attractive as a water supply. Silurian and Devonian carbonate aquifers also provide high yields and are used where unconsolidated aquifers provide an insufficient supply.

In 2002, Hancock County residents used approximately $6.07 \mathrm{Mgal} / \mathrm{d}$ of ground water (U.S. Geological Survey, 2004). Drinking water comes entirely from ground water (5.73 Mgal/d). Additional uses of ground water include livestock $(0.28 \mathrm{Mgal} / \mathrm{d})$, industry $(0.04 \mathrm{Mgal} / \mathrm{d})$, and irrigation (0.02 Mgal/d).

\section{Floods and Droughts}

Floods in the Sugar Creek and Leary Weber Ditch Basins can occur at various times of the year. Spring rains and snowmelt, in conjunction with frozen or saturated soils, often cause flooding. Summer flooding typically follows local, heavy thunderstorms that may deliver several inches of rain in 24 hours. Flooding also occurs in late fall and early winter when a combination of harvesting and vegetative dormancy leave 


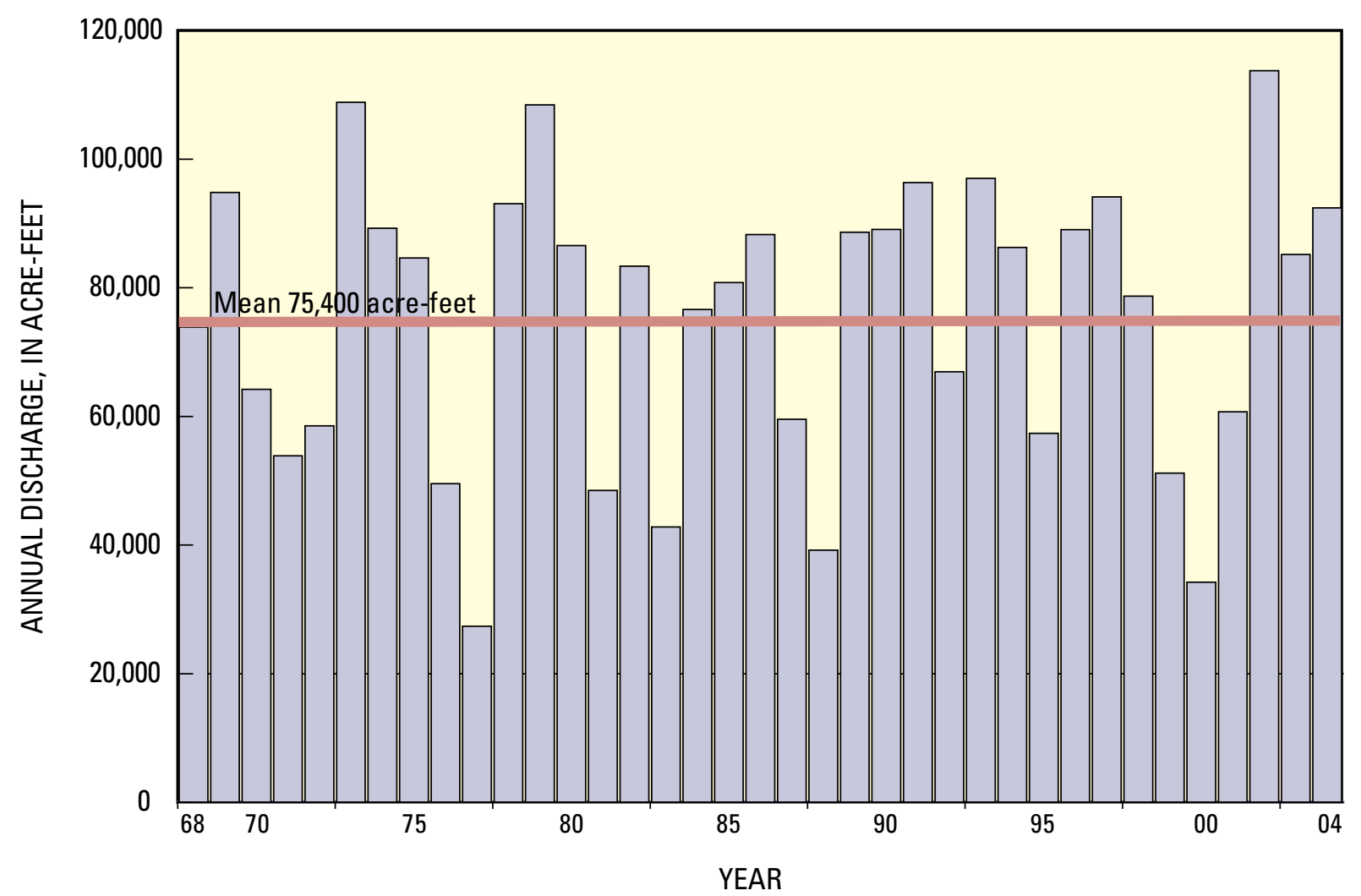

Figure 12. Annual discharge at U.S. Geological Survey streamflow-gaging station Sugar Creek at New Palestine, IN (03361650), water years 1968 to 2004 (water year is October through September).

little ground cover to slow or siphon rainwater. The largest flood in the Sugar Creek Basin occurred in 1913. It was likely the most-severe recorded flood in Indiana, with an estimated recurrence interval that exceeded 100 years (U.S. Geological Survey, 1991). Other major floods in central and southern Indiana were in 1937 and 1956. Since the gaging station on Sugar Creek at New Palestine was established in 1968, there have been several wet years of record. In November 1993, the gaging station recorded a mean daily discharge of $1,930 \mathrm{ft}^{3} / \mathrm{s}$, 18 times more than its mean daily discharge of $102.6 \mathrm{ft}^{3} / \mathrm{s}$. Peak instantaneous discharge was measured at $2,340 \mathrm{ft}^{3} / \mathrm{s}$. High stream stages also were recorded on February 23, 1979, at $10.34 \mathrm{ft}$ with a discharge of $1,500 \mathrm{ft}^{3} / \mathrm{s}$, and on December 30,1990 , at $10.31 \mathrm{ft}$ with a discharge of $2,259 \mathrm{ft}^{3} / \mathrm{s}$.

Droughts in central Indiana have lasted from weeks or months to years. The most-severe droughts have dried creeks, depleted reservoirs, and exhausted wells. The most-severe droughts in the study area were from June 1933 through September 1936, April 1952 through March 1957, and April 1962 through November 1966. The drought of June 1933 through September 1936 was the most severe on record, with a recurrence interval of 25 to 60 years (U.S. Geological Survey, 1991). Since the Sugar Creek at New Palestine gaging station was established, the 7-day minimum streamflow was $0.26 \mathrm{ft}^{3} / \mathrm{s}$, September 16-22, 1999. The 7-day minimum is defined as the lowest flow recorded over a continuous period of 7 days. On September 19, 1999, the overall lowest daily mean flow of $0.11 \mathrm{ft}^{3} / \mathrm{s}$ was recorded. Drought years recorded since the gaging station was constructed include 1988 and 1999 through 2001.

At the Leary Weber Ditch gaging station, there are only 2 complete years of record. Local flooding occurred on July 5 , 2003 , the highest discharge $\left(230 \mathrm{ft}^{3} / \mathrm{s}\right)$ for the period of record.

\section{Modifications to the Natural Hydrology}

Large amounts of subsurface drainage (tile drains) have been installed in the basins to improve the soils for farming and to improve yields. Tile drains lower seasonal water tables, permitting better timing of seasonal cultivation, lowering the cost of cultivation, and improving seed germination. Tile 

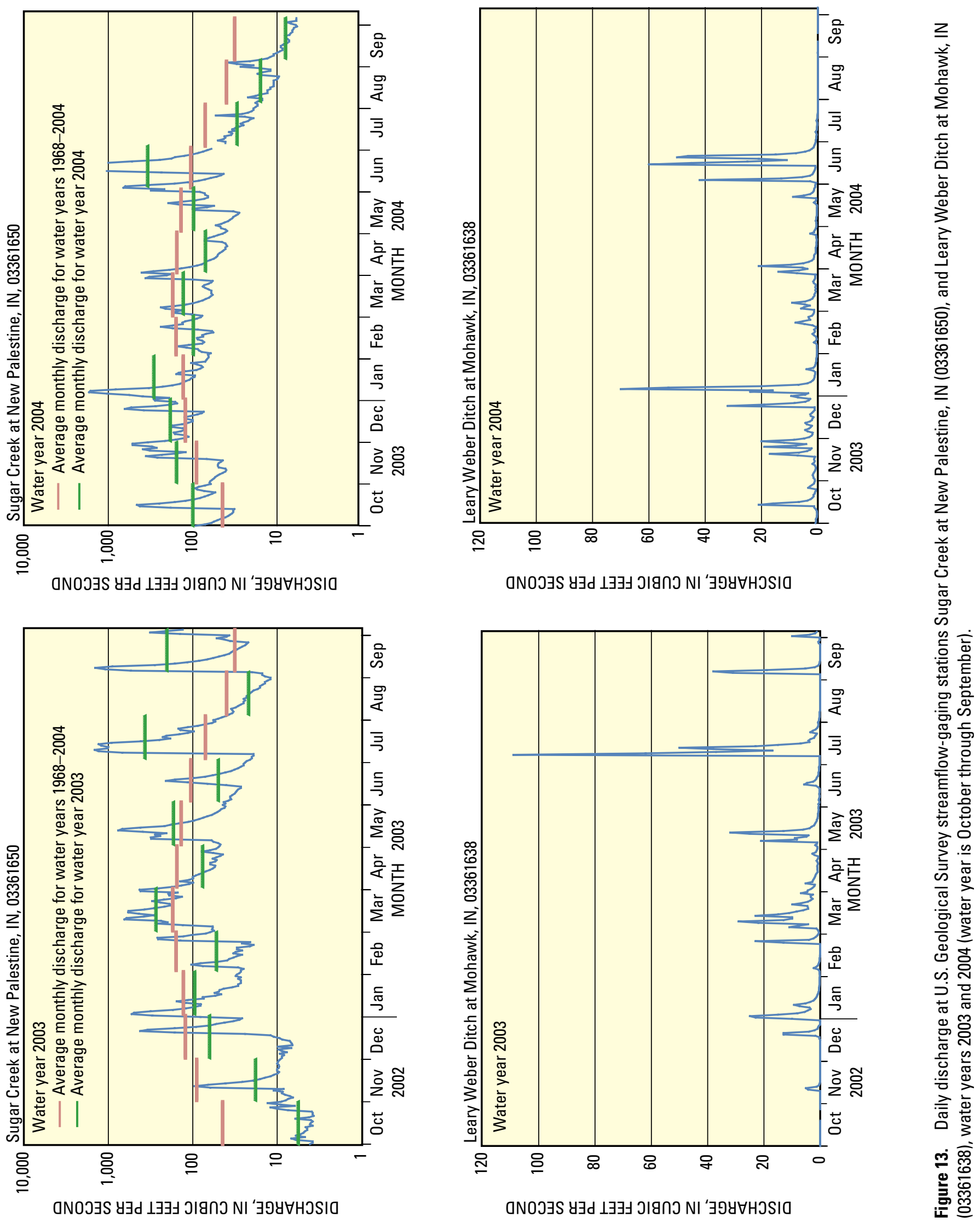
Table 5. Major features of aquifer settings in the Leary Weber Ditch and Sugar Creek Basins, Indiana (from Fenelon and Greeman, 1994).

[gal/min, gallon per minute; <, less than; > , greater than]

\begin{tabular}{lccccc}
\hline $\begin{array}{c}\text { Regional } \\
\text { aquifer system }\end{array}$ & Aquifer & $\begin{array}{c}\text { Aquifer } \\
\text { composition }\end{array}$ & $\begin{array}{c}\text { Recharge } \\
\text { characteristics }\end{array}$ & $\begin{array}{c}\text { Yield } \\
\text { (gal/min) }\end{array}$ & Contamination potential \\
\hline Surficial & $\begin{array}{c}\text { Surficial sand and } \\
\text { gravel }\end{array}$ & $\begin{array}{c}\text { Modern stream } \\
\text { and glaciofluvial } \\
\text { deposits }\end{array}$ & $\begin{array}{c}\text { High infiltration from } \\
\text { precipitation }\end{array}$ & 10 to 200 & High. \\
Surficial & $\begin{array}{c}\text { Discontinuous sand } \\
\text { and gravel }\end{array}$ & $\begin{array}{c}\text { Sand and gravel } \\
\text { lens within } \\
\text { glacial till }\end{array}$ & $\begin{array}{c}\text { Ground-water flow } \\
\text { through confining } \\
\text { layers }\end{array}$ & $<20$ & Medium. \\
Surficial & Buried sand and & Glaciofluvial \\
gravel & deposits & $\begin{array}{c}\text { Ground-water flow } \\
\text { through confining } \\
\text { layers }\end{array}$ & 50 to 225 & Medium. \\
Carbonate bedrock & $\begin{array}{c}\text { Silurian/Devonian } \\
\text { carbonates }\end{array}$ & Carbonate bedrock & $\begin{array}{c}\text { Ground-water flow } \\
\text { through confining } \\
\text { layers }\end{array}$ & 10 to $>1,000$ & Low to medium. \\
\hline
\end{tabular}

drains form a vast web of drainage conduits out of the agricultural fields of the basins. The drains greatly increase the rate of water exiting the field and subsequently speed the transport of chemicals and nutrients contained in the soils. The percentage of area in each basin with tile drains was estimated, based on soil-drainage characteristics. In the Sugar Creek Basin, only 29 percent of soils are moderately well to well drained (Fenelon, 1998). Therefore, approximately 71 percent of the area may be drained with either surface or subsurface methods. The entire Leary Weber Ditch Basin is poorly drained (Ruesch, 1978). Because 87 percent of the area is used for row-crop farming, it is estimated that 87 percent of the Leary Weber Ditch Basin is tile drained.

As it flows south, Sugar Creek is crossed by several major roads such as Interstate 70 and US 40, (fig. 1). These major thoroughfares have been constructed to minimize their impact on streams that they cross. Although some negative effects on water quality and biota in streams near other major water ways have been documented, the specific effect of nearby roads on Sugar Creek are unknown. In one study, differences in hydraulics and sediment deposition caused by highway runoff were shown to affect the biota, altering the abundance of pollution-sensitive macroinvertebrates (Maltby and others, 1995). Another study documented high levels of road salt in streams and determined a consequent reduction in the abundance and diversity of algae (Dickman and Gochnauer, 1978).
Several small wastewater-treatment plants are in the Sugar Creek Basin. One plant's outflow into Sugar Creek is $50 \mathrm{ft}$ upstream from the gaging station, Sugar Creek at New Palestine, IN. The outflow has an estimated discharge of $0.5 \mathrm{ft}^{3} / \mathrm{s}$. Water-quality samples are collected nearly $1.1 \mathrm{mi}$ above the gaging station and are unaffected by outflows from this treatment plant.

\section{The Agricultural Chemicals: Sources, Transport, and Fate Study in the Sugar Creek and Leary Weber Ditch Basins, Indiana}

The primary goal of the Agricultural Chemicals: Sources, Transport and Fate study is to identify the natural and human factors affecting the transport and fate of agricultural chemicals in several environmental settings. In the Sugar Creek and Leary Weber Ditch Basins, the study was designed to develop an understanding of the sources, pathways, and transformational processes that water and selected chemicals undergo during movement from a local field to a large river. In theory, a study using nested basins will allow comparison between a small-scale basin and a large-scale basin. By comparing findings in a nested small basin to those in the larger basin, effects 
of agricultural chemicals and hydrologic transport at larger geographic scales may be better understood. The goal of this study design is to illuminate the effects of agriculture upon streams and identify the fate of chemicals.

Sampling schedules for the ACT study allow analyses of chemical constituents in the Leary Weber Ditch Basin from their point of entry to the ditch until they flow into Sugar Creek. Constituent loss and degradation processes also can be observed. The basin is primarily an agricultural area and most chemical inputs are the result of crop production. The amount and timing of chemicals and nutrients applied to 45 percent of agricultural lands in the Leary Weber Ditch Basin were documented. From consultations with local farmers, the information they provided was used in addition to public records, area reconnaissance, and extrapolation to estimate the total amounts of herbicides, pesticides, and fertilizers applied to the Leary Weber Ditch and Sugar Creek Basins.

A wide variety of environmental-sampling sites were established throughout the Leary Weber Ditch Basin to measure the pathways of water and chemical movement in the various hydrologic compartments, including precipitation, tile drains, overland flow, vadose zone, ground water, and streams. Eight sampling sites were established: the North site, the South site, the Tile Drain site, the Overland Flow site, the Leary Weber Ditch Small Stream site, the Ground-Water and Surface-Water Interaction site (fig. 14), the Sugar Creek Indicator site, and the Sugar Creek Streamflow-Gaging Station site (fig. 11). A brief description and purpose of the sampling equipment used at each site is provided in table 6 . In addition, a detailed description of the sites with photographs and graphics is available on the internet (http://in.water.usgs. gov/NAWQAWHMI/act_map.php).

\section{Summary}

The Leary Weber Ditch Basin and the Sugar Creek Basin in central Indiana were selected for the Agricultural Chemicals: Sources, Transport, and Fate study as part of the U.S. Geological Survey's National Water-Quality Assessment Program. These basins have similar characteristics of physiography, geology, soils, climate, land use, and hydrology; there are also many differences because of size variations between the basins. Leary Weber Ditch is a small basin with homogeneous characteristics. Sugar Creek, which encompasses a larger area, has a higher degree of heterogeneity.

The Leary Weber Ditch Basin is nested completely within the Sugar Creek Basin. Leary Weber Ditch is a small, intermittent stream in Hancock County. It is primarily a tile-drain-fed stream. The Sugar Creek Basin spans parts of three counties, and the tributaries of Sugar Creek are mostly tile-drain fed. The primary land use in both basins is agriculture. There are no large towns or cities in either basin.

Both basins are contained completely within the New Castle Till Plains and Drainageways physiographic division.
There is little relief in either basin, but the gradients of Leary Weber Ditch and Sugar Creek differ substantially.

Most of the Sugar Creek Basin and the entire Leary Weber Ditch Basin overlie a combination of Devonian limestone and dolomite bedrock. The remaining part of the Sugar Creek Basin overlies either Silurian dolomite and limestone or Ordovician shale. Unconsolidated materials, sand, and gravel overlie the bedrock in much of the basins.

Soils in the Sugar Creek and Leary Weber Ditch Basins are identified broadly as either loam or silt loam. Soils are generally deep, poorly drained, of medium texture, and nearly level. Chances of surface erosion are negligible, and runoff is low. Available-water capacity is high. Natural fertility and organic matter are moderate. These soils are suited naturally to row crops such as corn and soybeans. Successful farming in the basins requires lowering the water table, removing ponded water, adding nutrients, and ensuring good soil tilth.

Crop land in the study area is divided nearly equally between corn and soybeans. Farming employs a wide variety of chemicals and practices to promote plant growth and to inhibit vegetative competition. The most-common growth enhancer is nitrogen. Glyphosate is the primary herbicide applied to soybeans, and atrazine is the primary herbicide applied to corn. Chlorpyrifos is the insecticide most widely used for pest control. Irrigation and manure application are minimal.

Modifications to the natural hydrology in the study area include installation of large amounts of subsurface drainage (tile drains) in the basin, the intersection of Sugar Creek by several major roads, and outflows from nearby wastewatertreatment plants. Tile drains permit better timing of seasonal cultivation and lower cultivation costs; they improve seed germination, but they also may facilitate the transport of water and chemicals into creeks and rivers. Several major roads cross Sugar Creek as it flows south, possibly affecting the hydrology and water quality of the area. Outflow from a water-treatment plant just upstream from the streamflowgaging station on Sugar Creek adds an estimated $0.5 \mathrm{ft}^{3} / \mathrm{s}$ of flow to the creek. Water-quality samples are collected nearly 1.1 mi upstream from the gaging station and are unaffected by plant outflows. Other small wastewater-treatment plants are in the Sugar Creek Basin.

The Sugar Creek and Leary Weber Ditch Basins exhibit moderate temperatures, ranging from a mean of $74.9^{\circ} \mathrm{F}$ in July to a mean of $25.2^{\circ} \mathrm{F}$ in January. The mean annual precipitation is $39.5 \mathrm{in}$. Normally, average annual precipitation is distributed evenly throughout the year; total amounts in spring and early summer exceed those of winter. Occasionally, heavy spring rains delay crop planting. Evapotranspiration plays a large role in the water budget of both basins.

Two streamflow-gaging stations were used to measure discharge in the study area-Leary Weber Ditch at Mohawk, IN (station number 03361638), and Sugar Creek at New Palestine, IN (station number 03361650). Mean daily streamflows for Sugar Creek $\left(102.6 \mathrm{ft}^{3} / \mathrm{s}\right)$ are higher than those at Leary Weber Ditch $\left(3.35 \mathrm{ft}^{3} / \mathrm{s}\right)$. Normally, higher flows start 


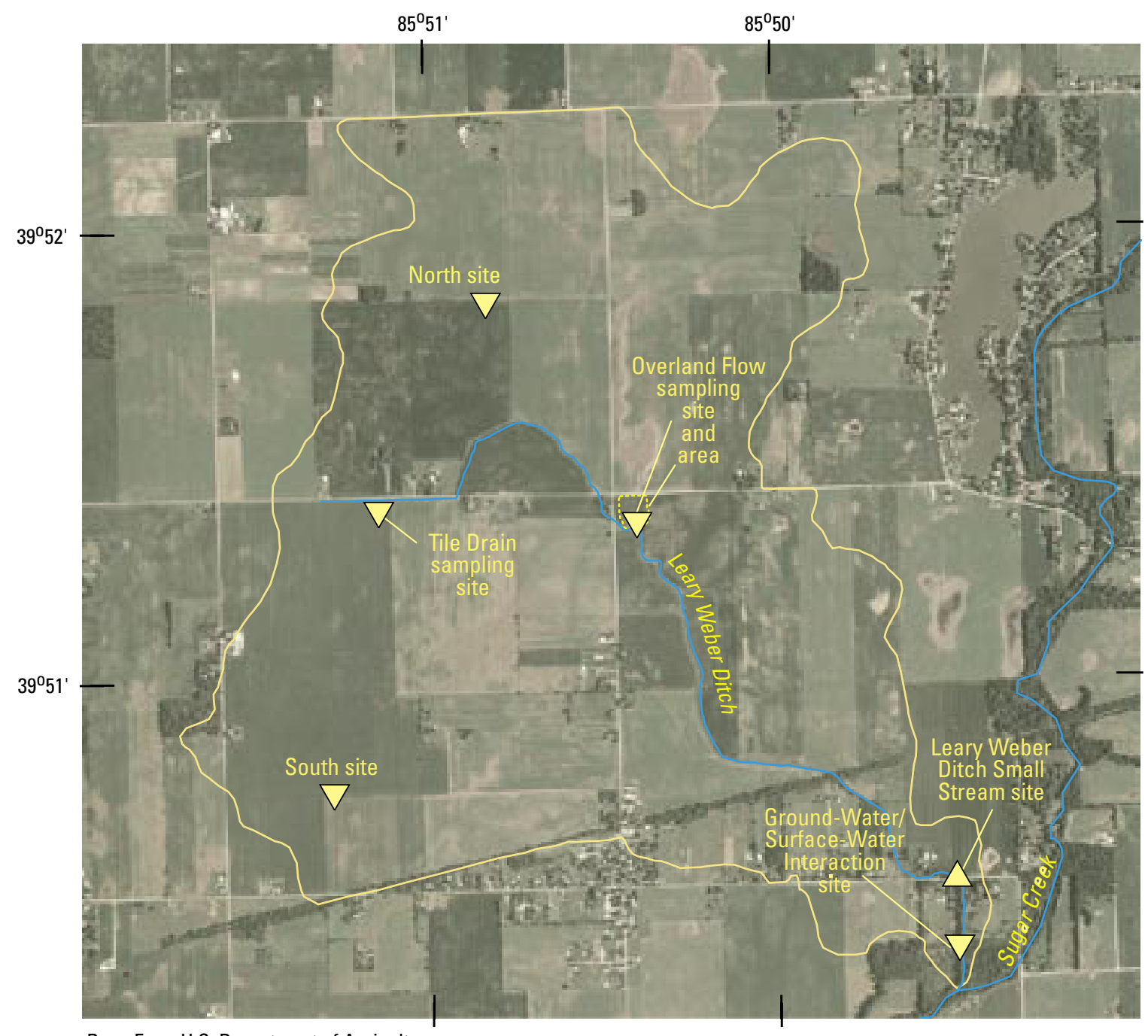

Base From U.S. Department of Agriculture,

2003 National Agricultural Imagery Program,

County Tiles for Indiana, Hancock, County.

Universal Transverse Mercator projection,

Zone 16, North American Datum, 1983

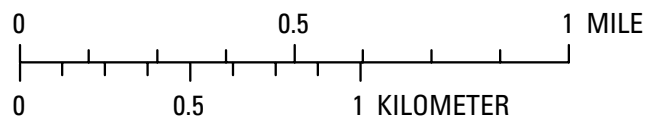

EXPLANATION

$\square$ Leary Weber Ditch Basin
$\triangle \quad$ U.S. Geological Survey streamflow-gaging station
$\nabla \quad$ U.S. Geological Survey water-quality station

Figure 14. Aerial photo showing location of sampling sites in Leary Weber Ditch Basin, Indiana. Sugar Creek Indicator site, U.S. Geological Survey 394340085524601 (fig. 11), is 9.9 miles downstream from the mouth of Leary Weber Ditch; Sugar Creek Streamflow-Gaging Station site, U.S. Geological Survey 03361650 (fig. 11), is 11 miles downstream from the mouth of Leary Weber Ditch. 
Table 6. Equipment list for the eight Agricultural Chemicals: Sources, Transport, and Fate study sites in the Leary Weber Ditch and Sugar Creek Basins, Indiana.

\begin{tabular}{|c|c|c|}
\hline Site & Equipment & Purpose \\
\hline \multirow[t]{10}{*}{ North } & Rain sampler & $\begin{array}{l}\text { Weekly wet-deposition collection. Analysis to quantify the amount of } \\
\text { pesticides and nutrients in rainwater. Water kept refrigerated prior to } \\
\text { collection. }\end{array}$ \\
\hline & Rain gage & Quantifies precipitation. \\
\hline & Pyranometer & Measures solar radiation. \\
\hline & Wind sentry & Measures wind strength and direction. \\
\hline & Net radiometer & $\begin{array}{l}\text { Measures the energy balance between incoming short-wave and long-wave } \\
\text { infrared radiation as opposed to surface-reflected short-wave and } \\
\text { outgoing long-wave infrared radiation. }\end{array}$ \\
\hline & Soil-temperature sensors & Measure the temperatures present in the subsurface. \\
\hline & Time-domain reflectometer & Measures the amount of water stored in the profile. \\
\hline & Heat-dissipation probes & $\begin{array}{l}\text { Measure the energy state of water in the soil. The energy state describes the } \\
\text { force that holds the water in the soil. }\end{array}$ \\
\hline & Pan lysimeters & $\begin{array}{l}\text { Collect water in the unsaturated zone to quantify the amount of pesticides } \\
\text { and nutrients in soil water. Sampled zone is from } 0 \text { to } 2 \text { feet below land } \\
\text { surface. }\end{array}$ \\
\hline & Suction lysimeters & $\begin{array}{l}\text { Porous ceramic cups that collect water in the unsaturated zone to quantify } \\
\text { the amount of pesticides, nutrients, and chemicals in unsaturated soil } \\
\text { water. Sample zones are } 3,4,5 \text {, and } 6 \text { feet below land surface. }\end{array}$ \\
\hline \multirow[t]{3}{*}{ South } & Rain gage & Used to quantify precipitation, allows comparison to North site. \\
\hline & Suction lysimeters & $\begin{array}{l}\text { Porous ceramic cups that collect water in the unsaturated zone to quantify } \\
\text { the amount of pesticides, nutrients, and chemicals in unsaturated soil } \\
\text { water. Sample zone is } 3,4,5 \text {, and } 6 \text { feet below land surface. Allow } \\
\text { comparison to North site. }\end{array}$ \\
\hline & Areal wells & $\begin{array}{l}\text { Three 4-inch, PVC wells are in the glacial till, screened at } 4.8,7.1 \text {, and } \\
9.2 \text { feet deep, respectively. One } 2 \text {-inch, PVC well is in a sand/gravel } \\
\text { lens, screened at } 14.5 \text { feet deep. Allow comparison to North site. }\end{array}$ \\
\hline \multirow[t]{3}{*}{ Tile Drain } & Flow monitor & Measures tile stage. \\
\hline & Auto sampler & $\begin{array}{l}\text { Preset rise in water levels triggers collection of discrete samples on preset } \\
\text { time scale. Water analyzed for pesticides, nutrients, and chemicals. }\end{array}$ \\
\hline & Data logger & $\begin{array}{l}\text { Records tile stage, ditch level, specific conductance, and temperature; } \\
\text { triggers auto sampler. }\end{array}$ \\
\hline
\end{tabular}


Table 6. Equipment list for the eight Agricultural Chemicals: Sources, Transport, and Fate study sites in the Leary Weber Ditch and Sugar Creek Basins, Indiana.-Continued

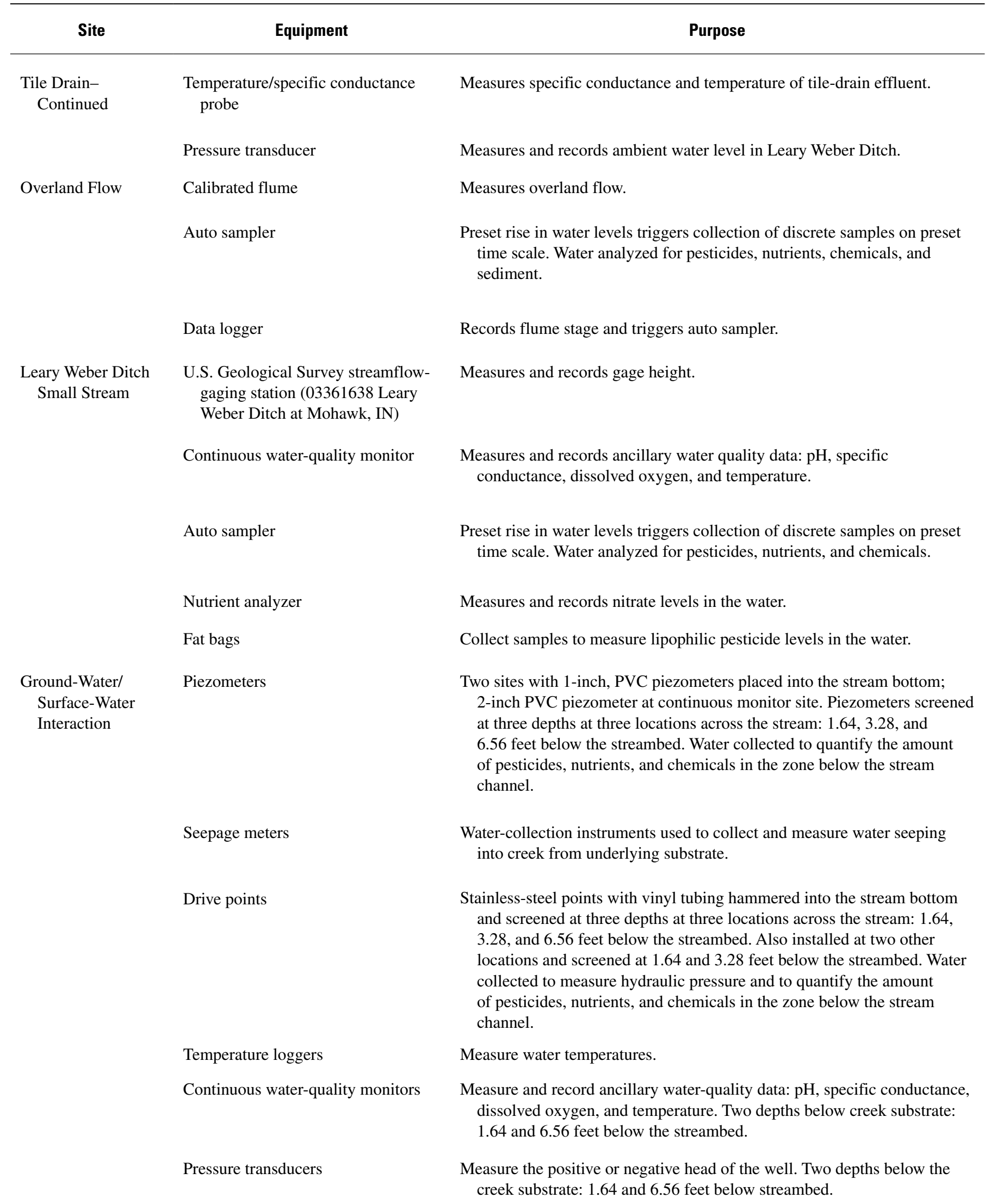


Table 6. Equipment list for the eight Agricultural Chemicals: Sources, Transport, and Fate study sites in the Leary Weber Ditch and Sugar Creek Basins, Indiana._-Continued

\begin{tabular}{|c|c|c|}
\hline Site & Equipment & Purpose \\
\hline \multirow[t]{2}{*}{$\begin{array}{l}\text { Ground-Water/ } \\
\text { Surface-Water } \\
\text { Interaction- } \\
\text { Continued }\end{array}$} & Overbank wells & $\begin{array}{l}\text { Water-collection wells placed into the bank near the stream were used to } \\
\text { sample lateral flow moving through the nearby substrate into or away } \\
\text { from the stream. Four depths below land surface: } 1.64,3.28,6.56 \text {, and } \\
9.84 \text { feet. Water collected to quantify the amount of pesticides, nutrients, } \\
\text { and chemicals. }\end{array}$ \\
\hline & Areal well & $\begin{array}{l}\text { Collect water in the saturated zone to quantify the amount of pesticides, } \\
\text { nutrients, and chemicals; } 2 \text {-inch PVC well screened at } 22.3 \text { feet below } \\
\text { land surface. }\end{array}$ \\
\hline \multirow[t]{2}{*}{$\begin{array}{l}\text { Sugar Creek } \\
\text { Indicator }\end{array}$} & $\begin{array}{l}\text { U.S. Geological Survey surface- } \\
\text { water wading stream site } \\
\text { (394340085524601 Sugar Creek } \\
\text { at County Road } 400 \mathrm{~S} \text { at New } \\
\text { Palestine, IN) }\end{array}$ & $\begin{array}{l}\text { Collection of water-quality samples. Water analyzed for pesticides, } \\
\text { nutrients, chemicals, and sediment. }\end{array}$ \\
\hline & Auto sampler & $\begin{array}{l}\text { Equipment automatically turned on by preset rise in water levels, causing } \\
\text { collection of discrete samples on preset time scale. Water analyzed for } \\
\text { pesticides, nutrients, chemicals, and sediment. }\end{array}$ \\
\hline \multirow[t]{2}{*}{$\begin{array}{l}\text { Sugar Creek } \\
\text { Streamflow- } \\
\text { Gaging Station }\end{array}$} & $\begin{array}{l}\text { U.S. Geological Survey streamflow- } \\
\text { gaging station (03361650 Sugar } \\
\text { Creek at New Palestine, IN) }\end{array}$ & Measures and records gage height. \\
\hline & Continuous water-quality monitor & $\begin{array}{l}\text { Measures and records ancillary water-quality data: } \mathrm{pH} \text {, specific } \\
\text { conductance, dissolved oxygen, and temperature. }\end{array}$ \\
\hline
\end{tabular}

in the late winter and continue through early summer. Snowmelt and rain play a major role in streamflows. Patterns of high or low flow at Leary Weber Ditch are consistent with high or low flows at Sugar Creek. At base flow, there is little to no input from ground water into Leary Weber Ditch. At base flow, Sugar Creek consists almost entirely of ground water; however, the total contribution from ground water into Sugar Creek is much lower than that of nearby basins. Sugar Creek is a perennial stream, but periods of very low flow to no flow were documented at Leary Weber Ditch. There were 97 days and 73 days of recorded no flow at Leary Weber Ditch during water years 2003 and 2004, respectively.

In the Sugar Creek and Leary Weber Ditch Basins, there are four major types of aquifers. The surficial sand and gravel aquifers are used frequently for drinking water and are adjacent to major drainages. Buried sand and gravel aquifers, which are found at different horizons in the drift, also are used for drinking water. Hancock County residents use 6.07 Mgal of ground water a day. Drinking water comes entirely from ground water (5.73 Mgal/d).
Floods and droughts occur periodically in the Sugar Creek and Leary Weber Ditch Basins. Floods are caused by spring rains on frozen or saturated soils, by heavy summer thunderstorms, and by fall rains after harvest. The largest recorded flood in the study area was in 1913, with a recurrence interval of 100 years. Periodic droughts in central Indiana have lasted from weeks to years. The most-severe drought ever recorded was 1933 through 1936, with a recurrence interval of 25 to 60 years. The record 7-day minimum streamflow recorded at the Sugar Creek gaging station was $0.26 \mathrm{ft}^{3} / \mathrm{s}$ on September 19, 1999.

The objectives of the Agricultural Chemicals topical study in the Leary Weber Ditch and Sugar Creek Basins are met by developing an annual mass budget for water and chemical constituents, determining residence times of water and chemicals in each hydrologic compartment, and by identifying chemical transformation and fate in each hydrologic compartment. Eight sampling sites were established to study the movement and processes that water and chemicals undergo within the basin. 


\section{Selected References}

Capel, P.D., Hamilton, P.A., and Erwin, M.L., 1994, Studies by the U.S. Geological Survey on sources, transport, and fate of agricultural chemicals: U.S. Geological Survey Fact Sheet 2004-3098, accessed February 15, 2005, at http://pubs.usgs.gov/fs/2004/3098/.

CityRating.com, 2002, Weather history, Indianapolis weather history, accessed March 24, 2005, at http://www.cityrating. com/cityweather.asp?city=Indianapolis

Clark, G.D, ed., 1980, The Indiana water resourceAvailability, uses, and needs: Governor's Water Resource Study Commission: Indiana Department of Natural Resources, p. 28-29.

Cornell University, 2005a, The Pesticide Management Education Program, Extoxnet, Extension Toxicology Network, Chlorpyrifos, accessed February 28, 2005, at http://pmep. cce.cornell.edu/profiles/extoxnet/carbaryl-dicrotophos/ chlorpyrifos-ext.html

Cornell University, 2005b, The Pesticide Management Education Program, Extoxnet, Extension Toxicology Network, Atrazine, accessed February 28, 2005, at http://pmep.cce. cornell.edu/profiles/extoxnet/24d-captan/atrazine-ext.html

Dickman, M.D., and Gochnauer, M.B., 1978, Impact of sodium chloride on the microbiota of a small stream: Environmental Pollution, v. 17, p. 109-126.

Erwin, M.L., Capel, P.D., and Baker, N.T., 2003, Sugar Creek Watershed selected for a national water-quality study: U.S. Geological Survey Fact Sheet 084-03, accessed February 15, 2005, at http://water.usgs.gov/pubs/fs/fs08403/.

Fenelon, J.M., 1998, Water quality in the White River Basin: U.S. Geological Survey Circular 1150, $10 \mathrm{p}$.

Fenelon, J.M., and Greeman, T.K., 1994, East Fork White River Basin, in Fenelon, J.M., and others, Hydrogeologic atlas of aquifers in Indiana: U.S. Geological Survey WaterResources Investigations Report 92-4142, p.135-156, accessed February 15, 2005, at http://in.water.usgs.gov/ atlasweb/.

Geolytics, Inc., 2000, CensusCD+Maps: East Brunswick, N.J., Geolytics, Inc., 1 CD-ROM.

Gray, H.H., 2000, Physiographic divisions of Indiana: Indiana University, Indiana Geological Survey Special Report 61, p. 6, accessed February 15, 2005, at http://igs.indiana.edu/ geology/maps/statephysiography/physiography.cfm

Gray, H.H., Droste, J.B., Patton, J.B., Rexroad, C.B., and Shaver, R.H., 1985, Correlation chart showing Paleozoic stratigraphic units of Indiana: Indiana Geological Survey Miscellaneous Map 48 supplemental chart.
Hasenmueller, N.R., and Bassett, J.L., 1980, Map of Indiana showing structure on top of Silurian rocks: Indiana Department of Natural Resources, Geological Survey, METC/EGSP Series 811, scale 1:500,000.

Indiana Agricultural Statistics Service, 2004, Indiana agricultural statistics-2003-2004, National Agricultural Statistics Service, accessed February 16, 2005, at http://www.nass. usda.gov/in/annbul/0304/2003_04.htm

Indiana Business Research Center 2005, State of Indiana and Indiana Department of Commerce, Stats Indiana-Hancock County, Indiana profile, Commuting patterns, accessed January 7, 2005, at http://www.stats.indiana.edu/profiles/ pr18059.html

Information Ventures, Inc., 1995, Glyphosate pesticide fact sheet, accessed March 15, 2005, at http://www.infoventures. com/e-hlth/pestcide/glyphos.html

Maltby, L., Boxall, A.B.A., Forrow, D.M., Calow, P., and Betton, C.I., 1995, The effects of motorway runoff on freshwater ecosystems-2. Identifying major toxicants: Environmental Toxicology and Chemistry, v. 14b, Abstract accessed February 16, 2005, at http://www.silsoe.cranfield. ac.uk/ecochemistry/publications/papers/201.pdf

National Agricultural Imagery Program, 2003, County tiles for Indiana, Hancock County, accessed May 4, 2006, at http:// www.indiana.edu/ gisdata/naip.html

National Climatic Data Center, 2004, U.S. monthly precipitation for cooperative and National Weather Service sites, Indiana, accessed April 28, 2005, at http://lwf.ncdc.noaa. gov/oa/climate/online/coop-precip.html

National Weather Service Forecast Office, 2005, Indianapolis, IN, Indianapolis climate, accessed January 13, 2005, at http://www.crh.noaa.gov/ind/cli.php

Purdue University Applied Meteorology Group, 2005a, Department of Agronomy, School of Agriculture Plant and Soils Laboratory, 2005, Normals 1971-2000, accessed January 13, 2005, at http://shadow.agry.purdue.edu/ sc.index.html

Purdue University Applied Meteorology Group, 2005b, Department of Agronomy, School of Agriculture Plant and Soils Laboratory, 2005, Hourly NWS and FAA, accessed April 28, 2005, at http://shadow.agry.purdue.edu/sc.index. html

Ruesch, D.R., 1978, Soil survey of Hancock County, Indiana: United States Department of Agriculture, Soil Conservation Service and Purdue University Agricultural Experiment Station, $60 \mathrm{p}$. 
Schneider, A.F., and Gray, H.H., 1966, Geology of the Upper East Fork Drainage Basin, Indiana: Indiana Department of Natural Resources, Geological Survey, Special Report No. 3, p. 9-30.

Shaver, R.H., Ault, C.H., Burger, A.M., Carr, D.D., Droste, J.D., Eggert, D.L., Gray, H.H., Harper, Denver, Hasenmueller, N.R., Hasenmueller, W.A., Horowitz, A.S., Hutchinson, H.C., Keith, B.D., Keller, S.J., Patton, J.B., Rexroad, C.B., and Weir, C.E., 1986, Compendium of Paleozoic rock-unit stratigraphy in Indiana-A revision: Bloomington, Ind., Indiana Geological Survey Bulletin 59, 203 p., accessed February 3, 2005, at http://igs.indiana.edu/geology/ structure/compendium/html/index.cfm

Todd, D.K., 1980, Groundwater hydrology (2d ed.): New York, Wiley, $225 \mathrm{p}$.

Trautmann, N.M., Porter, K.S., and Wagenet, R.J., 2005, Nitrogen-The essential element: Natural Resources Cornell Cooperative Extension, accessed March 15, 2005, at http://pmep.cce.cornell.edu/facts-slides-self/facts/ nit-el-grw89.html

U.S. Census Bureau, 2000, American FactFinder-Get a fact sheet for your community, accessed March 16, 2005, at http://factfinder.census.gov

U.S. Department of Agriculture, 2002, USDA National Agriculture Statistics Service, table 39, Fertilizers and chemicals applied-2002 and 1997, 2002 Census of Agriculture volume 1, County Level Data, Indiana, accessed April 11, 2005, at http://www.nass.usda.gov/census/ census02/volume1/.
U.S. Department of Agriculture, Natural Resources Conservation Service, 1994, State Soil Geographic (STATSGO) data base: U.S. Department of Agriculture, Natural Resources Conservation Service, digital data, accessed May 4, 2006, at http://www.ncgc.nrcs.usda.gov/products/datasets/statsgo/.

U.S. Department of Agriculture, Farm Services Agency, 2003, National Agricultural Imagery Program, County tiles for Indiana, Farm Services Agency digital data, accessed May 4, 2006, at http://www.apfo.usda.gov/NAIP.html

U.S. Geological Survey, 1983, Greenfield quadrangle, Indiana-Hancock Co.: U.S. Geological Survey Quadrangle Map DMA 3863 IV SE-Series V851, Scale 1:24,000.

U.S. Geological Survey, 1990, National water summary 1987-Hydrologic events and water supply and use: U.S. Geological Survey Water-Supply Paper 2350, 553 p.

U.S. Geological Survey, 1991, National water summary 1988-89-Hydrologic events—Floods and droughts: U.S. Geological Survey Water-Supply Paper 2375, p. 271-278, accessed February 23, 2005, at http://in.water. usgs.gov/drought/WSP-2375_in.pdf

U.S. Geological Survey, 2000, Indiana land cover data set: U.S. Geological Survey EROS Data Center, Sioux Falls, S.D., digital data, accessed May 4, 2006, at http://edc.usgs. gov/geodata/.

U.S. Geological Survey, 2004, Estimated use of water in the United States, County-Level data for 2000, Indiana State data file, Indiana, Hancock County, accessed March 16, 2005, at http://water.usgs.gov/watuse/data/2000/index.html

Wayne, W.J., 1963, Pleistocene formations in Indiana: Indiana Department of Conservation Geological Survey, Bulletin No. 25,85 p. 
